University of Louisville ThinkIR: The University of Louisville's Institutional Repository

Electronic Theses and Dissertations

$5-2016$

\title{
Investigating the influences of climate on the high elevation snowpack hydrology in the upper Colorado region.
}

Claire-Louise Bode

University of Louisville

Follow this and additional works at: https://ir.library.louisville.edu/etd

Part of the Hydrology Commons

\section{Recommended Citation}

Bode, Claire-Louise, "Investigating the influences of climate on the high elevation snowpack hydrology in the upper Colorado region." (2016). Electronic Theses and Dissertations. Paper 2444.

https://doi.org/10.18297/etd/2444

This Master's Thesis is brought to you for free and open access by ThinkIR: The University of Louisville's Institutional Repository. It has been accepted for inclusion in Electronic Theses and Dissertations by an authorized administrator of ThinkIR: The University of Louisville's Institutional Repository. This title appears here courtesy of the author, who has retained all other copyrights. For more information, please contact thinkir@louisville.edu. 
INVESTIGATING THE INFLUENCES OF CLIMATE ON HIGH ELEVATION SNOWPACK HYDROLOGY IN THE UPPER COLORADO REGION

By

\author{
Claire-Louise Bode \\ B. S., The Ohio State University, 2014

\begin{abstract}
A Thesis
Submitted to the Faculty of the

College of Arts and Sciences of the University of Louisville in Partial Fulfillment of the Requirements

for the Degree of
\end{abstract}

\author{
Master of Science \\ In Applied Geography \\ Department of Geography and Geosciences \\ University of Louisville \\ Louisville, KY
}

May 2016 
Copyright 2016 by Claire-Louise Bode

All rights reserved 

INVESTIGATING THE INFLUENCES OF CLIMATE ON HIGH ELEVATION SNOWPACK HYDROLOGY IN THE UPPER COLORADO REGION

$$
\text { By }
$$

Claire-Louise Bode

B. S., The Ohio State University, 2014

A Thesis Approved on

April 13, 2016

By the following Thesis Committee:

C. Andrew Day

Keith R. Mountain

Michael Croasdaile 


\section{ACKNOWLEDGMENTS}

I would like to thank the University of Louisville's Department of Geography and Geosciences for making this thesis possible, in particular Dr. C. Andrew Day for the assistance and guidance throughout my time in the Applied Geography program. I would especially like to thank Dr. C. Andrew Day for his guidance, inspiration and patience throughout the year. He has given me the inspiration and allowed me to become a better researcher. I would also like to thank the other committee members, Dr. Keith R. Mountain and Dr. Michael Croasdaile for their input along the way. Finally, I would like to thank my family and friends. They are my voice of reason, inspiration and daily reminders of what I want to achieve, even if they are on the other side of the World. Without them I would not have been able to make this thesis possible. 


\section{ABSTRACT \\ INVESTIGATING THE INFLUENCES OF CLIMATE ON HIGH ELEVATION SNOWPACK HYDROLOGY IN THE UPPER COLORADO REGION \\ Claire-Louise Bode \\ April 13, 2016}

A change in climate in the western United States has already affected and will continue to affect the onset of snow melt in many parts of the country. The effect of climate change on snow water equivalent, snowmelt runoff and total streamflow with respect to their elevation distribution is examined across the Colorado Headwaters Basin. This is a high altitude location within the Upper Colorado Basin region. The total streamflow of this region has a significant contribution from the spring season snow melt. An increase in air temperature in the Colorado Headwaters Basin over a few years will change the onset of the spring snowmelt for that season. These changes will affect many aspects of water management and utilization that the region is extremely dependent on. Snow water equivalent (SWE), mean/minimum air temperature and USGS stream gage data were collected and analyzed using Pearson correlation to assess whether warmer air temperatures corresponded to reduced snow water equivalent and streamflow discharge for each month at each station and gage in the basin at the 5\% level of statistical significance. A linear regression test followed to test for trends across a 30-year time period from 1986 to 2015, followed by a series of Runs tests for stationarity which are 
commonly employed statistical methods in the analysis of climate and water resource time series data.

As a result we see reductions in SWE and changes in snowmelt dominated streamflow timing from higher elevations. The timing, volume, and extent of mountain snowpack, and the associated snowmelt runoff, are intrinsically linked to seasonal climate variability and change. Recent observations have documented the changes in the early onset of snowmelt in the region and further indicate that the high altitude snowpacks may now be susceptible to the warming climate. 
TABLE OF CONTENTS

PAGE

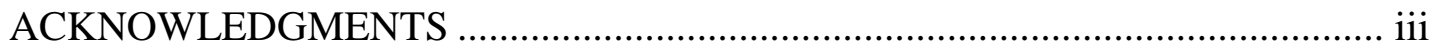

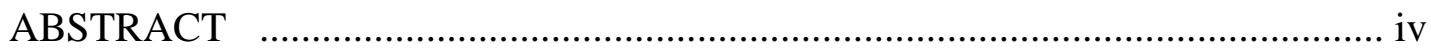

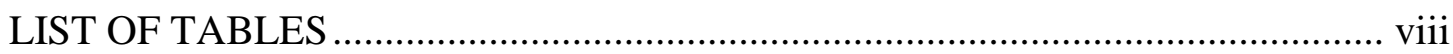

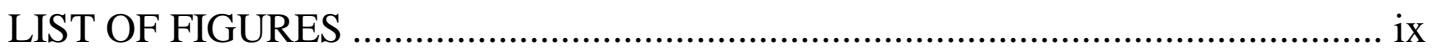

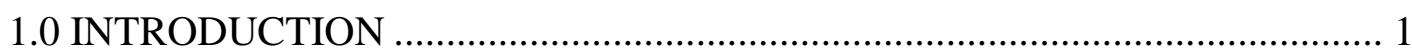

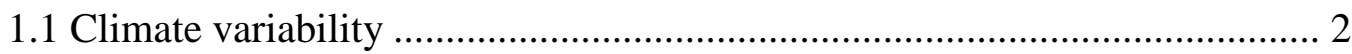

1.2 Current state of snowpack in the Western United States ................................ 3

1.3 How potential climate variability has impacted the snow stream

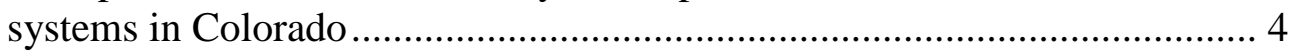

1.4 Trends in the snow water equivalent and snowmelt ..................................... 5

1.5 Techniques to identify changes in snow water equivalent.............................. 5

2.0 RESEARCH QUESTION AND HYPOTHESIS ............................................ 7

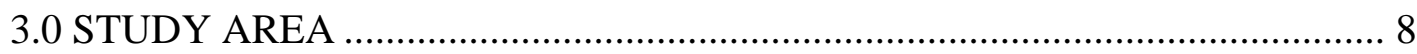

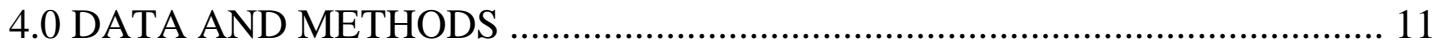

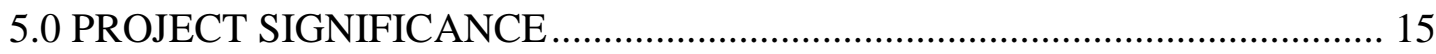

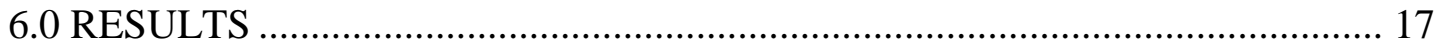

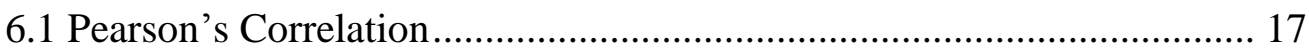

6.1.1 Pearson's Correlations of mean air temperature vs

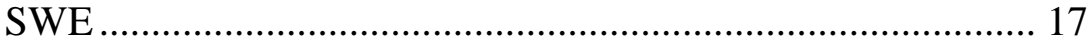

6.1.2 Pearson's Correlation of minimum air temperature vs

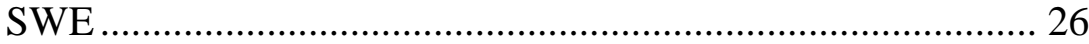

6.1.3 Pearson's Correlation of streamflow vs mean air temperature ........................................................................ 32

6.1.4 Pearson's Correlation of streamflow vs minimum air

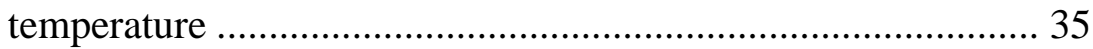

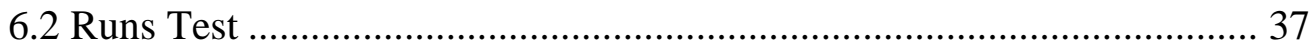

6.2.1 Runs Test of SWE, mean air temperature and minimum air temperature .................................................................. 37 


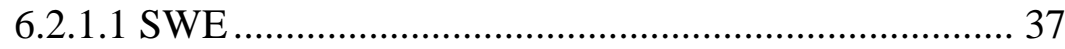

6.2.1.2 Mean air temperature _................................................... 38

6.2.1.3 Minimum air temperature ........................................... 39

6.2.2 Runs Test of Stream gages..................................................... 39

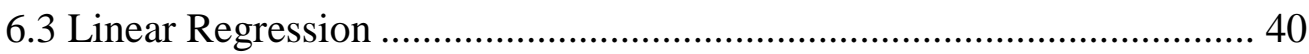

6.3.1 Linear Regression of SWE, mean air temperature and minimum air temperature........................................................ 40

6.3.1.1 SWE .................................................................. 41

6.3.1.2 Mean air temperature ................................................ 43

6.3.1.3 Minimum air temperature ............................................ 45

6.3.2 Linear Regression of the Stream gages....................................... 53

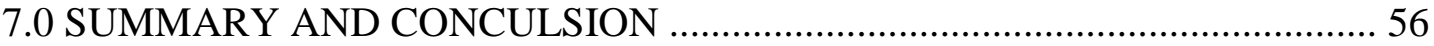

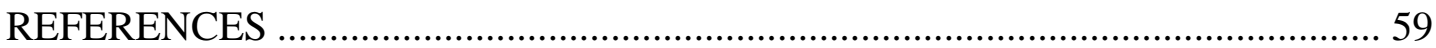

APPENDIX

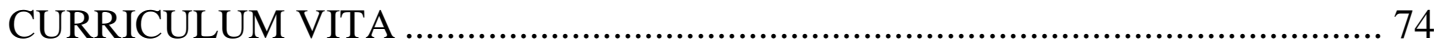




\section{LIST OF TABLES}

TABLE

1. List of the Basin and sub-basins included within the study area

2: List of the stream gauges in the study are that will be used to determine

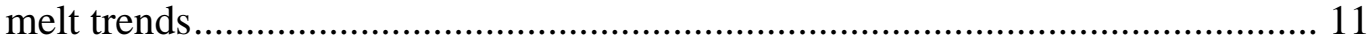

3. List of SNOTEL stations in the study area that will be used in the analysis ....... 12

4. Pearson's Correlation of Mean Air Temperature vs SWE................................. 23

5. Pearson's Correlation of Minimum Air Temperature vs SWE ........................... 29

6. Pearson's Correlation of Streamflow vs Mean Air Temperature ........................ 34

7. Pearson's Correlation of Streamflow vs Minimum Air Temperature ................. 36

8. Linear Regression and Runs Test for Stream gages in Study Area .................... 55

A1. Linear Regression and Runs Test for all 20 SNOTEL stations in Study ......... 62

A2. Change in Temperature over time for all SNOTEL stations .......................... 72 


\section{LIST OF FIGURES}

FIGURE

1. The study area with the SNOTEL stations that will be used for the study .......... 10

2. Locations of SNOTEL stations above $10,000 \mathrm{ft}(3,048 \mathrm{~m})$ in study area............ 19

3. Locations of SNOTEL stations below $10,000 \mathrm{ft}(3,048 \mathrm{~m})$ in study area ............ 22

4. Locations of Stream gages located in the study area .................................... 33

5. Mesa Lakes SWE variable time series trend graph ....................................... 47

6. Mesa Lakes Mean Air Temperature variable time series trend graph ................. 48

7. Mesa Lakes Minimum Air Temperature variable time series trend graph .......... 49

8. Kiln SWE variable time series trend graph.................................................. 50

9. Kiln Mean Air Temperature variable time series trend graph .......................... 51

10. Kiln Minimum Air Temperature variable time series trend graph .................... 52

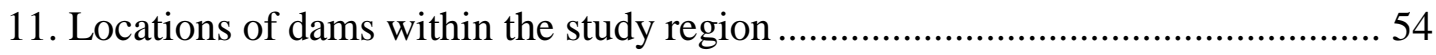




\subsection{INTRODUCTION}

What follows is a review of literature related to the issue of potential climate change in the high altitude snow packs of the Upper Colorado Region in the United States. Several studies have found that there is a link in declining snowpacks and earlier runoff to an increase in temperature in the American west (Knowles et al. 2006). In Colorado snow packs are an important source of water relied on as a steady supply of melt water for downstream usage by farmers, industries and recreational activities (Barnett et al. 2004). Most of this water comes from high-elevation mountains, which receive the majority of their annual precipitation as winter and spring snow (Serreze et al. 1999). This water accumulates as seasonal snowpacks, a natural reservoir storage system that can exceed the capacity of any man made storage system (Nijssen et al. 2001; Mote 2006).

The possibility of a long-term decline in annual average snowfall in a region can result in devastating consequences in the supply and availability of water, especially if

the snowpack that accumulates during the winter and spring months is heavily relied on for water storage and steady release during the subsequent drier summer months. The onset of snow melt, average air temperature and snow pack averages are shifting from stationary to non-stationary behavior, which will change the total water output for a region that uses snowmelt as its water resource (Milly et al. 2008). Stationary behavior forms the basis for a huge proportion of time series analysis methods, in which the statistical properties of the variable(s) in question do not change over time and fluctuate 
around a constant value. Non-stationary behaviors have means, variances and covariances that change over time.

\subsection{Climate variability}

Climate is usually defined as the average weather .The World Meteorological Organization defines the classical period for averaging these variables as 30 -years. The relevant quantities are most often surface variables such as temperature, precipitation, and wind. A change in the state of the climate (climate change) can be identified by changes in the mean and/or the variability of these variables that persist for an extended period, typically across decades or longer. Climate change may be due to natural internal processes or external forcings, or to persistent anthropogenic changes in the composition of the atmosphere or in land use. Climate variability refers to variations in the mean state and other statistics of the climate at all spatial and temporal scales beyond that of individual weather events. Variability may also be due to natural internal processes within the climate system, or to variations in natural or anthropogenic forcings (IPCC 2007). The Earth's climate is always changing and has gone through warmer and cooler periods in the past. Observations made by scientists around the world show that the Earth is experiencing a warming trend, as the average temperature has risen around 1 degree Fahrenheit over the past 100 years. This small change in climate can significantly impact SWE and the onset of snowmelt in high altitude regions of the globe (IPCC 2013).

Climate models using mathematical equations are programmed to simulate the climate as closely as possible to increase their ability to accurately predict any future 
trends. All climate models are predicting a warming trend; with the increase of surface temperatures having significant consequences on the hydrological cycle in regions where water supply is currently dominated by snowpacks and ice. Warming effects will lead to less winter precipitation to fall as snow and the melting of snow occurring earlier in the spring melt season, away from when the demand is highest in the Summer and Fall. A shift in peak river runoff, away from the summer, will be lost to the oceans as storage capacities are not sufficient. (Jourau et al 2005). The current climate models predict that the Earth's air temperature will keep rising over the next 100 years, with possible variation within this time. Some of the impacts of this trend are already occurring. Snow and ice cover is already decreasing in regions that were previously dominated by this land-cover, and other regions are experiencing an increase in flooding, water scarcity, land loss due to sea-level rise and the increased possibility of drought (IPCC 2013)

\subsection{Current state of snowpack in the western United States}

Observations since the 1960's have demonstrated that across the broader region of mountain areas across western North America, spring snow accumulation has declined (Mote et al. 2005) and the onset of snowmelt has occurred earlier in the year (Stewart et al. 2005). These changes and associated impacts have allowed scientists to develop a clearer understanding of how the regional climate is slowly shifting and impacting biophysical systems. This climatic shift is disrupting the normal variation of snowmelt and subsequent streamflow trends (Cayan 1996; Nijssen et al 2001). Across the Western United States climate trend changes are starting to affect the onset of seasonal snowmelt, leading to a shift in peak streamflow 
to earlier in the spring season with diminishing returns through the high-demand summer months (Mote 2003). The snow water equivalent (SWE) of snowpacks have also experienced decreasing trends over this time period due to a shift in climate (Clow 2010).

\subsection{How potential climate variability has impacted the snow and stream systems in Colorado}

Many studies have shown how changes in the melt and accumulation of seasonal snowpacks have led to a substantial reduction in the natural storage of water for the Western United States (Knowles et al. 2006). This has also been reflected in a decrease in the snow water equivalent (SWE) in snowpacks and an early onset of snowmelt during the spring months over the Colorado Headwaters region, which heavily relies on the high altitude snow packs as an important source of water (Cayan et al. 2001; McCabe and Clark 2005; Regonda et al. 2005; Stewart et al. 2005). These studies suggest that these changes are most felt where the mean winter temperatures are not usually very far below freezing (Stewart et al. 2005; Knowles et al. 2006; Mote 2006). As a consequence, only minor changes have generally been recorded in the snowmelt and stream flow timing in the Southern Rocky Mountains in Colorado (Clow 2010). The lack of change in these properties can be attributed to the region's cold continental climate and extreme elevations but recent observations now suggest otherwise as hydrologists have begun to document changes in the early onset of snowmelt across Colorado river basins and have further indicated that the high altitude snow packs in the Colorado region may now be susceptible to a warming climate (Clow 2010). 


\subsection{Trends in snow water equivalent and snowmelt}

Climate change has contributed to the changes in onset of snowmelt from an increase in temperature (Knowles et al. 2006) with the idea that there is also a longterm underlying trend. The change in snowmelt trends is consistent with findings in the study of reduced spring snowpacks (Mote et al. 2005) and the advancement of snow runoff (Stewart et al. 2005). Identifying these trends will allow for spatial and temporal data to be added to the pool of research bringing more interest to the study region and the possibility of expanding such studies. Previous studies have found that during the second half of the twentieth century, winter and spring warming of $2.5^{\circ} \mathrm{C}$ in the western United States have reduced spring snowpack at most locations (Hamlet et al. 2005). Accounting for the role of known patterns of climate variability, there is a substantial downward trend in overall snowpack in the western United States that is consistent with the observed warming. Widespread declines in springtime SWE have occurred in much of the North American West over the period 1982 to 2007 by 1 to $12 \mathrm{~cm}$ (Bedford et al. 2008). Decreasing trends in streamflow were found in the Northwest and South regions during the water year and spring-summer time periods.

The reduction in spring-summer flow in the western U.S. and Colorado regions could be due to decreases in mountain snowpack accumulation during the winter. (Kalra et al. 2008)

\subsection{Techniques to identify changes in snow water equivalent}

The literature shows that previous studies have used streamflow data to calculate and record the changes in the onset of snowmelt (Cayan et al. 2001; 
McCabe and Clark 2005; Stewart et al. 2005). There are few studies that evaluate the onset of snowmelt itself, as daily snowmelt records are relatively short-term. The primary data for detecting the onset of snowmelt in the form of SWE changes comes from the Natural Resource Conservation Service (NRCS). They operate an automated network of snowpack monitoring sites in the western United States, known as SNOTEL (snowpack telemetry). SNOTEL sites calculate the weight of snow on a liquid-filled pillow, measured by a pressure sensor, which is then converted to snow water equivalent on an hourly time step. Observations at SNOTEL stations that contain data over the last quarter of a decade further confirm that spring snow accumulations have declined (Mote et al. 2005) and that snowmelt and spring river runoff has started to peak earlier in the year (Stewart et al. 2005). The high temporal resolution of SNOTEL data allows researchers to further monitor changes in the total amount of snow accumulation to determine if the onset of snowmelt has changed. Although the SNOTEL record is short, its daily temporal resolution makes it uniquely suited towards the analysis of snowmelt timing trends. Most SNOTEL sites cover a 30-year time frame that allows water resource managers concerned with recent, and possible future, trends in precipitation and runoff linked to the potential changes in climate to analyze for mid-term climatic trend impacts (Clow 2010). 


\subsection{RESEARCH QUESTION AND HYPOTHESIS}

The research question for my thesis is "Has recent climate variability impacted the snow water equivalent and snow melt timing of the Colorado Headwaters Basin and, if so, are any trends observed over time?"

The proposed hypotheses are:

(1) Climate has an influence on the high altitude snowpacks in the Colorado Headwaters Basin.

(2) There has been a decline in snowpack hydrology as influenced by the climate of the Colorado Headwaters Basin.

(3) There has been a decline of SWE in the Colorado Headwaters Basin correlating with an increase in air temperature.

(4) A change in climate has affected the onset of snowmelt from the high altitude snowpacks in the Colorado Headwaters Basin. 


\subsection{STUDY AREA}

The area chosen for this study is the Colorado Headwaters watershed, which contains 6 sub-basins within the region (Table 1). The Colorado Headwaters watershed is located mostly on the middle to eastern side of the Upper Colorado Watershed region encompassing nine counties. This watershed includes almost 2,000 miles of tributaries that are capable of transporting the snowmelt through the valleys to the watershed outlet from high elevations (Figure 1). The stream gage located on the Colorado River near Cameo, CO (09095500) defines the outlet of the watershed where the Colorado River exits the basin and flows towards Utah (figure 4).

The region identified for the research question has over 30 years of SWE, air temperature and streamflow data and has major cities with big communities that will be affected if decreasing trends in snowmelt hydrology exist and continue to occur over the next few decades (Serreze et al. 1999). Identifying these trends will allow for spatial and temporal data to be added to the pool of research bringing more interest to the study region and the possibility of expanding such studies. 


\section{Table 1}

List of the Basin and sub-basins included within the study area.

\begin{tabular}{llc}
\hline Hydrological Unit Code & \multicolumn{1}{c}{ Name } & Drainage Area (sq miles) \\
\hline 1401 & Colorado Headwaters & $\sim 9,726$ \\
& Basin & \\
14010001 & Colorado Headwaters & 2,860 \\
14010002 & Blue & 680 \\
14010003 & Eagle & 945 \\
14010004 & Roaring Fork & 1,453 \\
14010005 & Colorado Headwaters- & 3,090 \\
& Plateau & 698 \\
\hline
\end{tabular}




\section{Figure 1}

Study area with the SNOTEL stations and stream gages that will be used for the study

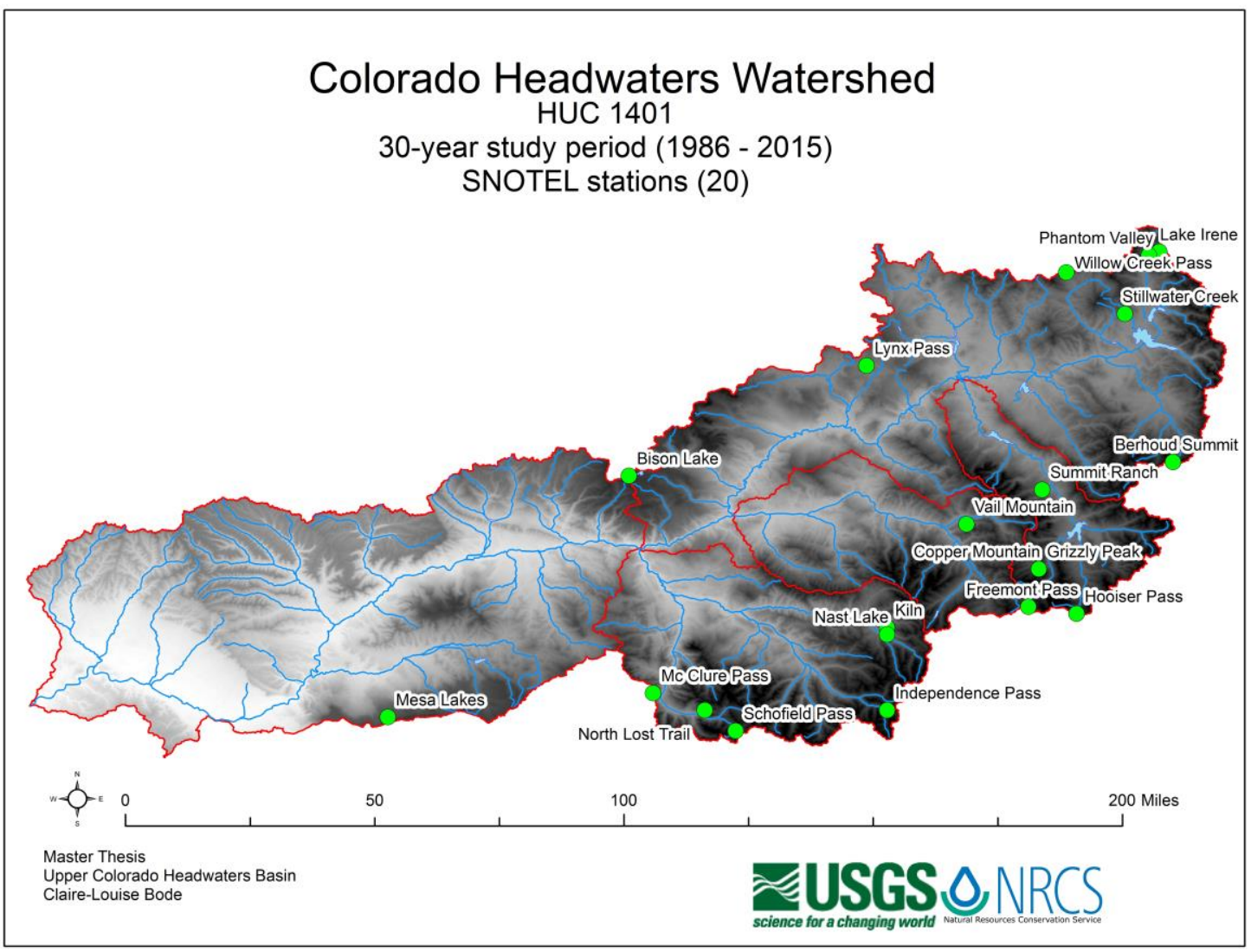




\subsection{DATA AND METHODS}

The United States Geological Survey (USGS) will provide monthly streamflow data at gauges located throughout and at the mouth of the Colorado Headwaters Basin (Table 2). The NRCS will provide monthly SWE and mean/minimum air temperature data as part of the SNOTEL database (Table 3). 20 out of the 30 automated stations present within the study area contain enough continuous data to be used in this study from 1986 to 2015 (Figure 1). The stations that do not contain the necessary data were discarded from the analysis. The data will only be collected for the months from January to June as these are significant to the winter and spring season in snowpack accumulation and melt.

\section{Table 2}

List of the stream gages in the study are that will be used to determine trends

\begin{tabular}{llccc}
\hline $\begin{array}{l}\text { Stream gauge } \\
\text { Code }\end{array}$ & Name & Elevation & $\begin{array}{l}\text { Drainage } \\
\text { Area }\end{array}$ & $\begin{array}{l}\text { Record } \\
\text { Begins }\end{array}$ \\
\hline 09095500 & $\begin{array}{l}\text { Colorado River } \\
\text { near Cameo } \\
\text { Colorado below } \\
\text { Glenwood }\end{array}$ & $5,813.73$ feet & $7,986 \mathrm{sq} \mathrm{mi}$ & 1933 \\
& $\begin{array}{l}\text { Springs } \\
\text { Colorado River } \\
\text { near Dotsero } \\
\text { Colorado River } \\
\text { near Kremmling }\end{array}$ & $6,720.73 \mathrm{feet}$ & $6,014 \mathrm{sq} \mathrm{mi}$ & 1966 \\
09070500 & 7,320 feet & $2,379 \mathrm{sq} \mathrm{mi}$ & 1904 \\
\hline
\end{tabular}


Table 3

List of SNOTEL stations in the study area that will be used in the analysis

\begin{tabular}{|c|c|c|c|c|c|c|}
\hline $\begin{array}{c}\text { STOTEL } \\
\text { station name }\end{array}$ & ID & Network & Elevation & County & $\begin{array}{l}\text { Start } \\
\text { Date }\end{array}$ & $\begin{array}{c}\text { Years of data } \\
\text { (Complete } \\
\text { from } \\
\text { January to } \\
\text { June) } \\
\end{array}$ \\
\hline Freemont Pass & 485 & SNTL & 11400 & Summit & 1981 & 35 \\
\hline $\begin{array}{l}\text { Hooiser Pass } \\
\text { Berhoud }\end{array}$ & 531 & SNTL & 11400 & Park & 1981 & 35 \\
\hline Summit & 335 & SNTL & 11300 & Grand & 1979 & 37 \\
\hline Grizzly Peak & 505 & SNTL & 11100 & Summit & 1981 & 35 \\
\hline Bison Lake & 345 & SNTL & 10880 & Garfield & 1986 & 30 \\
\hline Lake Irene & 565 & SNTL & 10700 & Grand & 1979 & 37 \\
\hline $\begin{array}{l}\text { Schofield Pass } \\
\text { Independence }\end{array}$ & 737 & SNTL & 10700 & Gunnison & 1986 & 30 \\
\hline $\begin{array}{l}\text { Pass } \\
\text { Copper }\end{array}$ & 542 & SNTL & 10600 & Pitkin & 1981 & 35 \\
\hline Mountain & 415 & SNTL & 10550 & Summit & 1979 & 37 \\
\hline Vail Mountain & 842 & SNTL & 10300 & Eagle & 1979 & 37 \\
\hline Mesa Lakes & 622 & SNTL & 10000 & Mesa & 1987 & 29 \\
\hline $\begin{array}{l}\text { Kiln } \\
\text { Willow Creek }\end{array}$ & 556 & SNTL & 9600 & Pitkin & 1981 & 35 \\
\hline Pass & 869 & SNTL & 9540 & Grand & 1979 & 37 \\
\hline Mc Clure Pass & 618 & SNTL & 9500 & Pitkin & 1981 & 35 \\
\hline Summit Ranch & 802 & SNTL & 9400 & Summit & 1981 & 35 \\
\hline North Lost Trail & 669 & SNTL & 9200 & Gunnison & 1986 & 30 \\
\hline Phantom Valley & 688 & SNTL & 9030 & Grand & 1981 & 35 \\
\hline Lynx Pass & 607 & SNTL & 8880 & Routt & 1981 & 35 \\
\hline Stillwater Creek & 793 & SNTL & 8720 & Grand & 1986 & 30 \\
\hline Nast Lake & 658 & SNTL & 8700 & Pitkin & 1986 & 30 \\
\hline
\end{tabular}


SPSS statistical software will allow a temporal analysis of the monthly SWE, mean/minimum air temperature and streamflow data for each gage/station. Firstly Pearson correlation will assess whether warmer air temperatures correspond to reduced SWE and streamflow discharge for each month at each station/gage. Following this linear regression will test for trends across the time period, with the SWE, air temperature and streamflow data as the dependent variables and the year as the independent variable. SPSS will create a series of output tables, R-squared values (\% of variance the regression explains), and the p-value (compared to 5\% level of statistical significance). The unstandardized coefficient data (B and SE) for the constant and year data will provide the necessary components for the linear regression trend formula.

Finally a runs test will test for the presence of randomness or stationarity in the time series datasets. The runs test statistic $(\mathrm{Z})$ values produced will determine if any of the datasets display a switch from a stationary to non-stationary pattern over time. A negative Z-value, for example, highlights a downward developing non-stationary trend over the time period suggesting ongoing climate change in the region. These values will again be analyzed at the 5\% significance level. These statistical methods are commonly employed in the analysis of climate and water resource time series data to test for trends and non-stationarity (Helsel and Hirsch 2002).

It is expected that the results of this analysis will identify negative trends for SWE indicating that an earlier shift in the onset of snowmelt within the watershed is occurring (Knowles et al. 2006). The mean air temperature should show an increasing trend to correlate with the negative SWE trend as the warming climate will allow for conditions for the onset of snowmelt to occur earlier in the season. As a result we should also expect 
to see an increase in streamflow earlier in the melt season due to the onset of snowmelt.

This will correlate with the potential decrease of SWE which will relate to the findings of Clow (2010) and the need to study this phenomenon within smaller areas of the western United States further. 


\subsection{PROJECT SIGNIFICANCE}

This project is significant because the effects of climate change and variability are being felt at all spatial scales with the potential to affect large populations (Mote, 2003). The Rocky Mountains in Colorado create 4 regional watersheds in which streamflow originates in the high elevation slopes primarily as snowmelt. This accounts for up to $90 \%$ of the water supply of 19 Western States of the United States in which more than two-thirds of the population live outside of the hydrologic boundaries of the basin. Furthermore, $18 \%$ of Colorado's population relies on the groundwater supplied by this snowmelt resource. As a result water in this region is very important in supplying the demands of agriculture, municipal, recreation, fisheries, industrial and commercial uses (Barnett et al. 2009).

Water distribution from this watershed historically has been stretched to breaking point due to a combination of population growth, long-term climate change and decadal scale droughts affecting nearly every part of the Colorado River Basin. This river basin is a major artery that supports a multi-billion dollar recreational economy that includes such outdoor activities as; water rafting, boating, kayaking, fly fishing, birding, hunting, and hiking, which attracts tens of millions of outdoor enthusiasts worldwide boosting the tourism economy to the area (Barnett et al. 2009). The river is also used as a power source for hydroelectric facilities in the basin. It generates approximately 12 billion kilowatt-hours annually, which is a critical supplemental supply to the peak power and base load that is used to support the broader western US power grids. The individual 
issues within this basin are complex and the relationships between them are still not fully understood (Christensen et al. 2004).

More effort needs to be made to understand the fragile balance between water supply, demand and changes in the onset of snowmelt and stream flow timing leading to potentially harmful changes in the watershed. New information needs to be generated for this area to inform the population making clear what the future could bring with expectations and solutions for the management of the Colorado Headwaters Basin (Barnett et al. 2004). Reductions in mountain snowpack and changes in snowmelt derived streamflow timing in the key melting seasons from the higher elevations are of great concern in regions where the human water demand is already equaled or exceeds the total amount of water available today. It is important to measure and track the changing trends of SWE as the mountain snowpack serves as the natural reservoir for the cold precipitation during the winter months to the dry, hot valleys and large populations downstream. The timing and extent of high elevation snowpack, and the streamflow timing are all linked to seasonal climate variability and change. 


\subsection{RESULTS}

\subsection{Pearson's Correlation}

\subsubsection{Pearson's Correlation for Mean Air Temperature vs SWE}

Above 11,000 feet (3352 m) -

3 SNOTEL stations (Hoosier Pass), 335 (Berthoud Summit) and 505 (Grizzly Peak) displayed significant negative correlation between April mean air temperature and May SWE, with r-values ranging from -0.576 - -0.67 (Table 4). These three SNOTEL stations also displayed a significant negative correlation between May mean air temperature and June SWE, with r-values ranging from -0.441 - -0.71 (Table 4) A further station (485, Freemont Pass) also displayed significant negative correlation between May mean air temperature and June SWE (r-value -0.422).

All 4 SNOTEL stations above 11,000 feet, displayed significant negative correlations between the mean air temperature and the SWE for each station (figure 2).

Between 10,000 and 11,000 feet (Between $3048 \mathrm{~m}$ and $3352 \mathrm{~m}$ ) -

Only one SNOTEL station (Vail Mountain) 842 displayed significant negative correlations between March mean air temperature vs April SWE, April average mean temperature vs May SWE and May average mean temperature and June SWE. The rvalues range from $-0.602--0.682$ (Table 4). Furthermore 5 SNOTEL stations 345 (Bison 
Lake), 565 (Lake Irene), 737 (Schofield Pass), 415 (Copper Mountain) and 622 (Mesa Lake) displayed significant negative correlation between April average mean temperature vs May SWE and May average mean temperature and June SWE, with r-values ranging from -0.415 - -0.988 (Table 4). SNOTEL Station 542 (Independence Pass) displayed a significant negative correlation only in the April mean temperature vs May SWE (r-value -0.627 (Table 4)).

There are 7 SNOTEL stations that currently display significant negative correlation between their mean air temperatures and SWE between 10,000 feet and 11,000 feet. This give us a total of 11 SNOTEL stations in the Colorado Headwaters Basin that show significant negative correlations between the mean air temperature and SWE located between 10,000 feet and 11,000 feet for the previously discussed correlations between the mean air temperature and SWE (figure 2). 
Figure 2

Locations of SNOTEL station above $10,000 \mathrm{ft}(3,048 \mathrm{~m})$

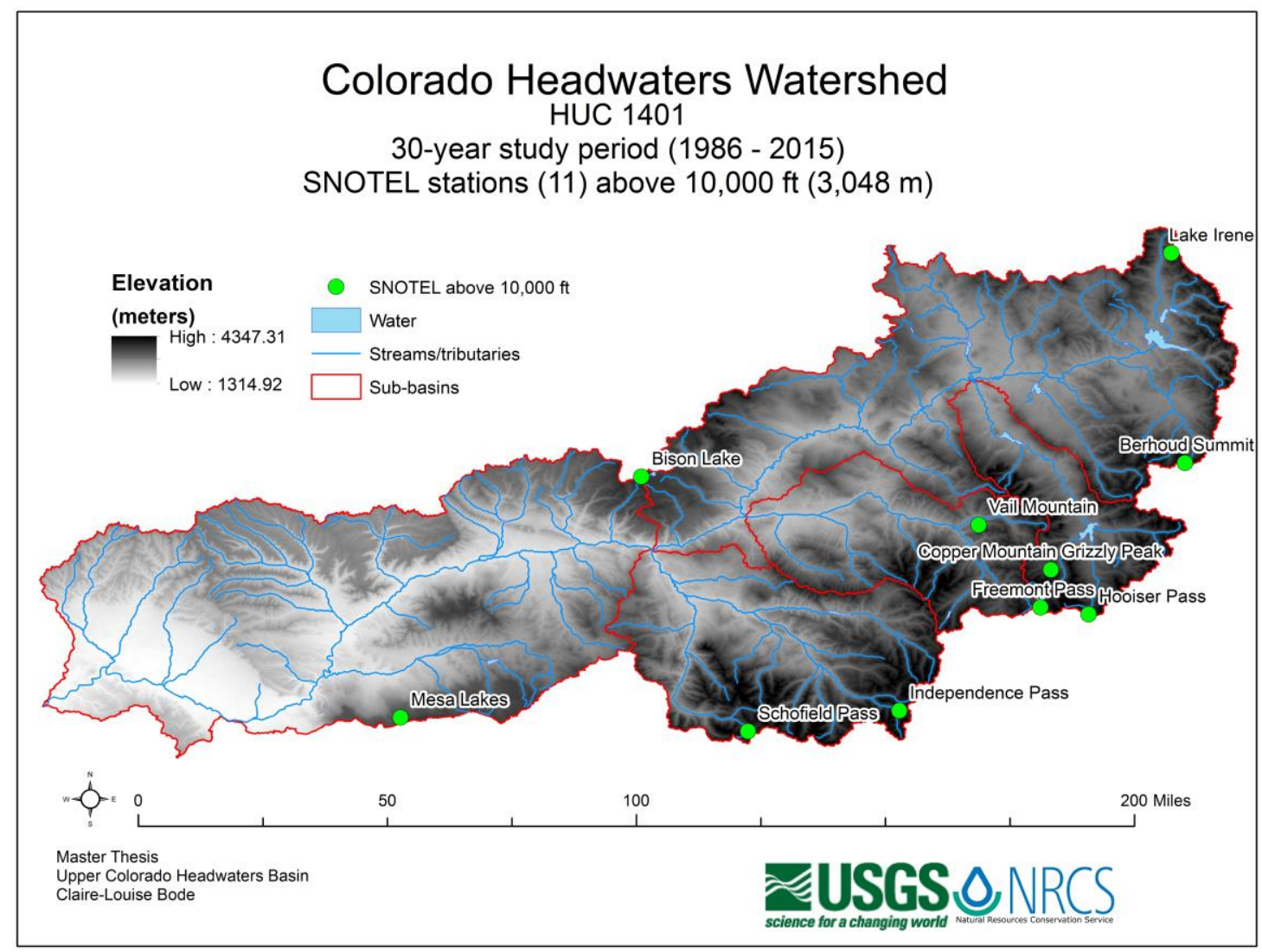


Below 10,000 feet (3048 m) -

SNOTEL station 618 (McClure Pass) was the only station that displayed significant negative correlation between March mean air temperature vs April SWE, April mean air temperature vs May SWE and May mean air temperature vs June SWE. The r-values ranged from -0.391 - -0.796 (Table 4). 4 SNOTEL stations (Kiln) 556, (Willow Creek Pass) 869, (Summit Ranch) 802 and (North Lost Trail) 669 displayed significant negative correlation between April mean air temperature vs May SWE and May mean air temperature and June SWE, with r-values raging from -0.474 - -0.775 (Table 4).

SNOTEL station (Phantom Valley) 688 had its only display of negative correlation in the April mean air temperature vs May SWE (r-value -0.6 (Table 4)). A total of 6 SNOTEL stations above 9,000 feet showed negative correlations between the mean air temperature and SWE. There was a significant negative correlation for SNOTEL station 793 (Still Water Creek) for March mean air temperature vs April SWE and April mean air temperature vs May SWE, with r-values ranging from -0.39 - -0.472 (Table 4). A furthermore 2 SNOTEL stations Lynx Pass) 607 and (Nast Lake) 658 displayed a strong negative correlation between April mean air temperature vs May SWE, with r-values ranging from $-0.551--0.771$ (Table 4).

A total of 9 SNOTEL stations displayed significant negative correlation between the mean air temperatures and SWE below 10,000 feet (figure 3).

It is noted that 19 out of the 20 stations displayed significant negative correlation for the April mean air temperature vs May SWE. It was expected to see negative trends 
throughout the basin corresponding to the onset of snow melt due to the increase in average air temperature in the Colorado Headwaters Basin. For the May air temperature vs June SWE there are 17 SNOTEL stations, all of which are located above 9,000 feet, which display a strong significant negative correlation. Of the 17 SNOTEL stations there are 11 SNOTEL stations that display this significant negative trend located above 10,000 feet (figure 2).

The data shows that there is a more statistically significant correlation between the April mean air temperature and SWE and the May mean air temperature and SWE. This is important to highlight, as it is the key melting period for the season and is a helpful indicator of the amount of water available in the spring and summer months following the cold season. Temperatures and SWE measurements on or around April 1 SWE are a good indicator of both the peak snowpack and the total amount of cold season precipitation for the season.

Water that is produced by snowmelt is an important part of the annual water cycle in many parts of the world, and for some cases it contributes to a large part of the annual runoff in a watershed. Predicting the snowmelt runoff from a drainage basin is a key factor towards designing water control projects as rapid snowmelt can cause flooding and decreased SWE over the important winter accumulation months can indicate a decrease in storage for the following summer months. 
Figure 3

Location of SNOTEL stations below 10,000 ft (3.048m)

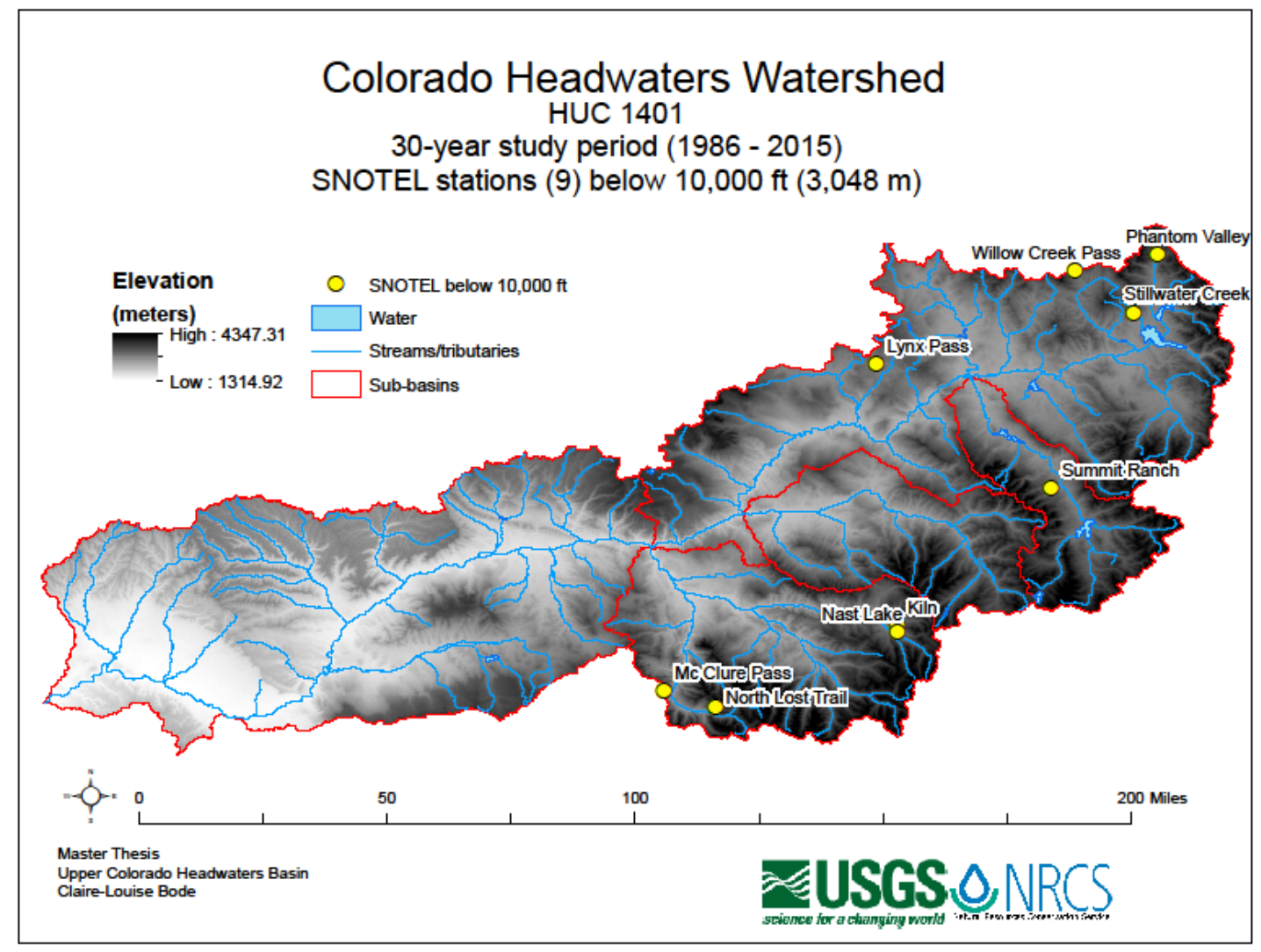


Table 4

Pearson's Correlation of mean air temperature vs SWE

\begin{tabular}{|c|c|c|c|c|c|c|}
\hline $\begin{array}{l}\text { Station } \\
\text { Name and } \\
\text { ID }\end{array}$ & & $\begin{array}{c}\text { Jan } \\
\text { Mean } \\
\text { AirTemp } \\
\text { vs Feb } \\
\text { SWE }\end{array}$ & $\begin{array}{c}\text { Feb } \\
\text { Mean } \\
\text { AirTemp } \\
\text { vs Mar } \\
\text { SWE }\end{array}$ & $\begin{array}{c}\text { Mar } \\
\text { Mean } \\
\text { AirTemp } \\
\text { vs Apr } \\
\text { SWE }\end{array}$ & $\begin{array}{c}\text { Apr } \\
\text { Mean } \\
\text { AirTemp } \\
\text { vsMay } \\
\text { SWE }\end{array}$ & $\begin{array}{c}\text { May } \\
\text { Mean } \\
\text { AirTemp } \\
\text { vs June } \\
\text { SWE }\end{array}$ \\
\hline \multirow[t]{2}{*}{$\begin{array}{l}\text { Freemont } \\
\text { Pass (485) }\end{array}$} & $\begin{array}{l}\text { Pearson } \\
\text { Correlation }\end{array}$ & -0.065 & 0.253 & 0.025 & -0.215 & -0.422 \\
\hline & Sig & 0.734 & 0.177 & 0.894 & 0.253 & 0.02 \\
\hline \multirow[t]{2}{*}{$\begin{array}{l}\text { Hoosier Pass } \\
(531)\end{array}$} & $\begin{array}{l}\text { Pearson } \\
\text { Correlation }\end{array}$ & 0.056 & 0.311 & -0.073 & -0.635 & -0.456 \\
\hline & $\mathrm{Sig}$ & 0.769 & 0.094 & 0.701 & 0 & 0.011 \\
\hline \multirow[t]{2}{*}{$\begin{array}{l}\text { Berthoud } \\
\text { Summit } \\
(335)\end{array}$} & $\begin{array}{l}\text { Pearson } \\
\text { Correlation }\end{array}$ & -0.163 & -0.065 & -0.306 & -0.576 & -0.441 \\
\hline & Sig & 0.388 & 0.734 & 0.107 & 0.001 & 0.015 \\
\hline \multirow[t]{2}{*}{$\begin{array}{l}\text { Grizzly } \\
\text { Peak(505) }\end{array}$} & $\begin{array}{l}\text { Pearson } \\
\text { Correlation }\end{array}$ & -0.05 & 0.014 & -0.046 & -0.67 & -0.71 \\
\hline & Sig & 0.793 & 0.943 & 0.818 & 0 & 0 \\
\hline \multirow[t]{2}{*}{$\begin{array}{l}\text { Bison Lake } \\
(345)\end{array}$} & $\begin{array}{l}\text { Pearson } \\
\text { Correlation }\end{array}$ & 0.102 & -0.055 & -0.159 & -0.622 & -0.602 \\
\hline & Sig & 0.59 & 0.774 & 0.401 & 0 & 0 \\
\hline \multirow[t]{2}{*}{$\begin{array}{l}\text { Lake Irene } \\
(565)\end{array}$} & $\begin{array}{l}\text { Pearson } \\
\text { Correlation }\end{array}$ & -0.067 & 0.002 & -0.124 & -0.56 & -0.682 \\
\hline & Sig & 0.726 & 0.99 & 0.522 & 0.001 & 0 \\
\hline \multirow[t]{2}{*}{$\begin{array}{l}\text { Schofield } \\
\text { Pass (737) }\end{array}$} & $\begin{array}{l}\text { Pearson } \\
\text { Correlation }\end{array}$ & 0.114 & 0.11 & -0.247 & -0.988 & -0.649 \\
\hline & Sig & 0.548 & 0.569 & 0.197 & 0 & 0 \\
\hline \multirow[t]{2}{*}{$\begin{array}{l}\text { Independence } \\
\text { Pass (542) }\end{array}$} & $\begin{array}{l}\text { Pearson } \\
\text { Correlation }\end{array}$ & 0.278 & 0.288 & -0.113 & -0.627 & -0.232 \\
\hline & Sig & 0.144 & 0.123 & 0.553 & 0 & 0.218 \\
\hline
\end{tabular}


Table 4 Continued

Pearson's Correlation of mean air temperature vs SWE

\begin{tabular}{|c|c|c|c|c|c|c|}
\hline $\begin{array}{l}\text { Station } \\
\text { Name }\end{array}$ & & $\begin{array}{c}\text { Jan } \\
\text { Mean } \\
\text { AirTemp } \\
\text { vs Feb } \\
\text { SWE }\end{array}$ & $\begin{array}{c}\text { Feb } \\
\text { Mean } \\
\text { AirTemp } \\
\text { vs Mar } \\
\text { SWE }\end{array}$ & $\begin{array}{c}\text { Mar } \\
\text { Mean } \\
\text { AirTemp } \\
\text { vs Apr } \\
\text { SWE }\end{array}$ & $\begin{array}{c}\text { Apr } \\
\text { Mean } \\
\text { AirTemp } \\
\text { vsMay } \\
\text { SWE }\end{array}$ & $\begin{array}{c}\text { May } \\
\text { Mean } \\
\text { AirTem } \\
\text { p vs } \\
\text { June } \\
\text { SWE }\end{array}$ \\
\hline \multirow[t]{2}{*}{$\begin{array}{l}\text { Copper } \\
\text { Mountain } \\
(415)\end{array}$} & $\begin{array}{l}\text { Pearson } \\
\text { Correlation }\end{array}$ & -0.028 & 0.064 & -0.136 & -0.559 & -0.575 \\
\hline & Sig & 0.883 & 0.736 & 0.475 & 0.001 & 0.001 \\
\hline \multirow[t]{2}{*}{$\begin{array}{l}\text { Vail } \\
\text { Mountain } \\
(842)\end{array}$} & $\begin{array}{l}\text { Pearson } \\
\text { Correlation }\end{array}$ & -0.153 & -0.128 & -0.433 & -0.633 & -0.609 \\
\hline & Sig & 0.419 & 0.501 & 0.017 & 0 & 0 \\
\hline \multirow[t]{2}{*}{$\begin{array}{l}\text { Mesa- } \\
\text { Lake } \\
(622)\end{array}$} & $\begin{array}{l}\text { Pearson } \\
\text { Correlation }\end{array}$ & 0.131 & 0.035 & -0.281 & -0.696 & -0.415 \\
\hline & Sig & 0.489 & 0.855 & 0.133 & 0 & 0.023 \\
\hline \multirow[t]{2}{*}{$\begin{array}{l}\text { Kiln } \\
(556)\end{array}$} & $\begin{array}{l}\text { Pearson } \\
\text { Correlation }\end{array}$ & 0.049 & 0.152 & -0.254 & -0.744 & -0.474 \\
\hline & Sig & 0.802 & 0.432 & 0.184 & 0 & 0.009 \\
\hline \multirow[t]{2}{*}{$\begin{array}{l}\text { Willow } \\
\text { Creek } \\
\text { Pass } \\
(869)\end{array}$} & $\begin{array}{l}\text { Pearson } \\
\text { Correlation }\end{array}$ & 0.133 & 0.321 & 0.188 & -0.552 & -0.561 \\
\hline & Sig & 0.492 & 0.083 & 0.321 & 0.002 & 0.001 \\
\hline \multirow[t]{2}{*}{$\begin{array}{l}\text { McClure } \\
\text { Pass } \\
(618)\end{array}$} & $\begin{array}{l}\text { Pearson } \\
\text { Correlation }\end{array}$ & -0.106 & -0.128 & -0.391 & -0.796 & -0.592 \\
\hline & Sig & 0.598 & 0.509 & 0.036 & 0 & 0.001 \\
\hline \multirow[t]{2}{*}{$\begin{array}{l}\text { Summit } \\
\text { Ranch } \\
(802)\end{array}$} & $\begin{array}{l}\text { Pearson } \\
\text { Correlation }\end{array}$ & 0.097 & 0.005 & -0.184 & -0.775 & -0.387 \\
\hline & Sig & 0.611 & 0.981 & 0.331 & 0 & 0.034 \\
\hline \multirow[t]{2}{*}{$\begin{array}{l}\text { North } \\
\text { Lost } \\
(669)\end{array}$} & $\begin{array}{l}\text { Pearson } \\
\text { Correlation }\end{array}$ & 0.132 & 0.002 & -0.194 & -0.735 & -0.582 \\
\hline & Sig & 0.503 & 0.991 & 0.305 & 0 & 0.001 \\
\hline
\end{tabular}


Table 4 Continued

Pearson's Correlation of mean air temperature and SWE

\begin{tabular}{|c|c|c|c|c|c|c|}
\hline \multicolumn{2}{|c|}{$\begin{array}{l}\text { Station } \\
\text { Name }\end{array}$} & $\begin{array}{c}\text { Jan } \\
\text { Mean } \\
\text { AirTe } \\
\text { mp vs } \\
\text { Feb } \\
\text { SWE }\end{array}$ & $\begin{array}{c}\text { Feb } \\
\text { Mean } \\
\text { AirTem } \\
\text { p vs } \\
\text { Mar } \\
\text { SWE }\end{array}$ & $\begin{array}{c}\text { Mar } \\
\text { Mean } \\
\text { AirTe } \\
\text { mp vs } \\
\text { Apr } \\
\text { SWE }\end{array}$ & $\begin{array}{c}\text { Apr } \\
\text { Mean } \\
\text { AirTe } \\
\text { mp } \\
\text { vsMay } \\
\text { SWE }\end{array}$ & $\begin{array}{c}\text { May } \\
\text { Mean } \\
\text { AirTem } \\
\text { p vs } \\
\text { June } \\
\text { SWE }\end{array}$ \\
\hline \multirow[t]{2}{*}{$\begin{array}{l}\text { Phantom } \\
\text { Valley } \\
(688)\end{array}$} & $\begin{array}{l}\text { Pearson } \\
\text { Correlation }\end{array}$ & -0.064 & 0.007 & -0.284 & -0.6 & -0.352 \\
\hline & Sig & 0.737 & 0.971 & 0.128 & 0 & 0.057 \\
\hline \multirow[t]{2}{*}{$\begin{array}{l}\text { Lynx } \\
\text { Pass } \\
(607)\end{array}$} & $\begin{array}{l}\text { Pearson } \\
\text { Correlation }\end{array}$ & 0.239 & 0.212 & -0.273 & -0.771 & -0.348 \\
\hline & Sig & 0.203 & 0.261 & 0.145 & 0 & 0.059 \\
\hline \multirow[t]{2}{*}{$\begin{array}{l}\text { Still } \\
\text { Water } \\
\text { Creek } \\
(793)\end{array}$} & $\begin{array}{l}\text { Pearson } \\
\text { Correlation }\end{array}$ & 0.215 & 0.121 & -0.39 & -0.472 & $*$ \\
\hline & Sig & 0.264 & 0.523 & 0.037 & 0.008 & \\
\hline \multirow[t]{2}{*}{$\begin{array}{l}\text { Nast } \\
\text { Lake } \\
(658)\end{array}$} & $\begin{array}{l}\text { Pearson } \\
\text { Correlation }\end{array}$ & 0.12 & 0.114 & -0.133 & -0.551 & -0.079 \\
\hline & Sig & 0.528 & 0.554 & 0.483 & 0.002 & 0.684 \\
\hline
\end{tabular}

* no data 


\subsubsection{Pearson's Correlation for Minimum Air Temp vs SWE}

Above 11,000 feet (3352 m)

SNOTEL station (Berthoud Summit) 335 displayed significant negative correlation for April minimum air temperature vs May SWE and May minimum air temperature vs June SWE, with r-values ranging between $-0.38--0.393$ (Table 5). A further SNOTEL station (Hoosier Pass) 531 showed significant correlation between May minimum air temperature vs June SWE (r-value -0.373 (Table 5)). There are only 2 SNOTEL stations that show significant negative correlations for minimum air temperature and SWE above 11,000 feet.

Between 10,000 and 11,000 feet (between $3048 \mathrm{~m}$ and $3352 \mathrm{~m}$ ) -

3 SNOTEL Stations (Bison Lake) 345, (Schofield Pass) 737 and (Copper Mountain) 415 displayed significant negative correlation for April minimum air temperature vs May SWE and May minimum air temperature vs June SWE, with r-values ranging between $-0.372--0.519$ (Table 5). A further 3 SNOTEL stations displayed a significant negative correlation for April minimum air temperature vs May SWE, with rvalues ranging from $-0.454--0.485$ (Table 5).

There are a total of 6 SNOTEL stations that display a strong negative correlation above 10,000 feet. This gives a total of 8 SNOTEL stations that display significant negative correlation above 10,000 feet with in the Colorado Headwaters Basin (figure 2). 
Below 10,000 feet (3048 m) -

Only 1 SNOTEL station displays a significant negative correlation in the early months of the year. SNOTEL station (Willow Creek Pass) 869 displays a negative correlation (r-value 0.337) for the March minimum air temperature vs April SWE. A further 4 SNOTEL stations (Kiln) 556, (McClure) 618, (Summit Ranch) 802 and (North Lost Trail) 669 located within the basin show significant negative correlation for April minimum air temperature vs May SWE, with r-values ranging from $-0.445--0.547$ (Table 5). There are a total of 5 SNOTEL stations above 9,000 feet that show a negative correlation.

Another SNOTEL station (Still Water Creek) 793 displayed a negative correlation (r-value -0.462) for the May minimum air temperature vs June SWE. There are a total of 6 SNOTEL stations below 10,000 feet that displayed a strong negative correlation between minimum air temperature and SWE for the Colorado Headwaters basin.

A total of 8 SNOTEL stations showed significant negative correlation above 10,000 feet within the study area for minimum air temperature vs SWE. A further 6 SNOTEL stations showed significant negative correlation within the study area but were located below 10,000 feet (figure 3). 17 SNOTEL stations displayed a strong negative correlation for April minimum air temperature vs May SWE, and 12 of those are statistically significant (Table 5). The data shows that there is a more statistically significant correlation between the April mean air temperature and SWE and the May mean air temperature and SWE than that of any of the other months that were tested. 
Overall there was more correlation between the mean air temperature and SWE than there was with the minimum air temperature and SWE for all the SNOTEL stations located in the geographical study region of the Colorado Headwaters Basin. There are more SNOTEL stations with results that were significantly negative in correlation over the study period years than that of the minimum air temperature and SWE over the same time frame. This is due to the data for minimum air temperature only accounting for one day of the month where the mean average temperature accounts for all days within the month. 
Table 5

Pearson's Correlation of Minimum Air Temperature vs SWE

\begin{tabular}{|c|c|c|c|c|c|c|}
\hline $\begin{array}{l}\text { Station } \\
\text { Name }\end{array}$ & & $\begin{array}{c}\text { Jan Min } \\
\text { AirTemp } \\
\text { vs Feb } \\
\text { SWE }\end{array}$ & $\begin{array}{c}\text { Feb Min } \\
\text { AirTemp } \\
\text { vs Mar } \\
\text { SWE }\end{array}$ & $\begin{array}{c}\text { Mar Min } \\
\text { AirTemp } \\
\text { vs Apr } \\
\text { SWE }\end{array}$ & $\begin{array}{c}\text { Apr Min } \\
\text { AirTemp } \\
\text { vsMay } \\
\text { SWE }\end{array}$ & $\begin{array}{c}\text { May } \\
\text { Min } \\
\text { AirTemp } \\
\text { vs June } \\
\text { SWE }\end{array}$ \\
\hline \multirow[t]{2}{*}{$\begin{array}{l}\text { Freemont } \\
\text { Pass (485) }\end{array}$} & $\begin{array}{l}\text { Pearson } \\
\text { Correlation }\end{array}$ & -0.108 & 0.049 & 0.216 & 0.029 & -0.321 \\
\hline & Sig & 0.569 & 0.796 & 0.252 & 0.879 & 0.083 \\
\hline \multirow[t]{2}{*}{$\begin{array}{l}\text { Hoosier } \\
\text { Pass (531) }\end{array}$} & $\begin{array}{l}\text { Pearson } \\
\text { Correlation }\end{array}$ & -0.073 & 0.089 & 0.085 & -0.352 & -0.373 \\
\hline & Sig & 0.7 & 0.64 & 0.656 & 0.057 & 0.0442 \\
\hline \multirow[t]{2}{*}{$\begin{array}{l}\text { Berthoud } \\
\text { Summit } \\
(335)\end{array}$} & $\begin{array}{l}\text { Pearson } \\
\text { Correlation }\end{array}$ & -0.25 & -0.268 & 0.127 & -0.38 & -0.393 \\
\hline & Sig & 0.183 & 0.153 & 0.511 & 0.042 & 0.032 \\
\hline \multirow[t]{2}{*}{$\begin{array}{l}\text { Grizzly } \\
\text { Peak (505) }\end{array}$} & $\begin{array}{l}\text { Pearson } \\
\text { Correlation }\end{array}$ & 0.146 & -0.359 & 0.25 & -0.277 & -0.177 \\
\hline & Sig & 0.44 & 0.056 & 0.2 & 0.153 & 0.349 \\
\hline \multirow[t]{2}{*}{$\begin{array}{l}\text { Bison } \\
\text { Lake (345) }\end{array}$} & $\begin{array}{l}\text { Pearson } \\
\text { Correlation }\end{array}$ & 0.228 & -0.298 & 0.044 & -0.434 & -0.432 \\
\hline & Sig & 0.225 & 0.109 & 0.817 & 0.017 & 0.017 \\
\hline \multirow[t]{2}{*}{$\begin{array}{l}\text { Lake Irene } \\
(565)\end{array}$} & $\begin{array}{l}\text { Pearson } \\
\text { Correlation }\end{array}$ & -0.321 & -0.348 & 0.118 & -0.209 & -0.134 \\
\hline & Sig & 0.083 & 0.064 & 0.541 & 0.267 & 0.48 \\
\hline \multirow[t]{2}{*}{$\begin{array}{l}\text { Schofield } \\
\text { Pass (737) }\end{array}$} & $\begin{array}{l}\text { Pearson } \\
\text { Correlation }\end{array}$ & 0.02 & -0.179 & -0.185 & -0.591 & -0.462 \\
\hline & Sig & 0.916 & 0.352 & 0.337 & 0.001 & 0.012 \\
\hline
\end{tabular}


Table 5 Continued

Pearson's Correlation of minimum air temperature and SWE

\begin{tabular}{|c|c|c|c|c|c|c|}
\hline $\begin{array}{l}\text { Station } \\
\text { Name }\end{array}$ & & $\begin{array}{c}\text { Jan Min } \\
\text { AirTemp } \\
\text { vs Feb } \\
\text { SWE }\end{array}$ & $\begin{array}{c}\text { Feb Min } \\
\text { AirTemp } \\
\text { vs Mar } \\
\text { SWE }\end{array}$ & $\begin{array}{c}\text { Mar Min } \\
\text { AirTemp } \\
\text { vs Apr } \\
\text { SWE }\end{array}$ & $\begin{array}{c}\text { Apr Min } \\
\text { AirTemp } \\
\text { vsMay } \\
\text { SWE }\end{array}$ & $\begin{array}{c}\text { May } \\
\text { Min } \\
\text { AirTemp } \\
\text { vs June } \\
\text { SWE }\end{array}$ \\
\hline \multirow[t]{2}{*}{$\begin{array}{l}\text { Independence } \\
\text { Pass (542) }\end{array}$} & $\begin{array}{l}\text { Pearson } \\
\text { Correlation }\end{array}$ & 0.115 & -0.088 & -0.202 & -0.485 & -0.051 \\
\hline & Sig & 0.553 & 0.644 & 0.284 & 0.007 & 0.788 \\
\hline \multirow[t]{2}{*}{$\begin{array}{l}\text { Copper } \\
\text { Mountain } \\
(415)\end{array}$} & $\begin{array}{l}\text { Pearson } \\
\text { Correlation }\end{array}$ & -0.033 & -0.273 & 0.156 & -0.372 & -0.418 \\
\hline & Sig & 0.863 & 0.144 & 0.41 & 0.043 & 0.024 \\
\hline \multirow[t]{2}{*}{$\begin{array}{l}\text { Vail } \\
\text { Mountain } \\
(842)\end{array}$} & $\begin{array}{l}\text { Pearson } \\
\text { Correlation }\end{array}$ & -0.071 & -0.113 & 0.077 & -0.454 & -0.222 \\
\hline & Sig & 0.71 & 0.554 & 0.687 & 0.012 & 0.238 \\
\hline \multirow[t]{2}{*}{$\begin{array}{l}\text { Mesa Lakes } \\
(622)\end{array}$} & $\begin{array}{l}\text { Pearson } \\
\text { Correlation }\end{array}$ & 0.098 & 0.267 & 0.04 & -0.472 & 0.057 \\
\hline & Sig & 0.607 & 0.153 & 0.833 & 0.008 & 0.767 \\
\hline \multirow[t]{2}{*}{ Kiln (556) } & $\begin{array}{l}\text { Pearson } \\
\text { Correlation }\end{array}$ & 0.005 & -0.081 & -0.119 & -0.514 & -0.195 \\
\hline & Sig & 0.98 & 0.678 & 0.54 & 0.004 & 0.312 \\
\hline $\begin{array}{l}\text { Willow } \\
\text { Creek Pass } \\
(869)\end{array}$ & $\begin{array}{l}\text { Pearson } \\
\text { Correlation }\end{array}$ & 0.203 & 0.251 & 0.337 & -0.057 & -0.13 \\
\hline Pass & Sig & 0.29 & 0.181 & 0.069 & 0.763 & 0.495 \\
\hline \multirow[t]{2}{*}{$\begin{array}{l}\text { McClure } \\
\text { Pass (618) }\end{array}$} & $\begin{array}{l}\text { Pearson } \\
\text { Correlation }\end{array}$ & -0.027 & -0.054 & -0.156 & -0.536 & -0.032 \\
\hline & Sig & 0.893 & 0.785 & 0.419 & 0.003 & 0.869 \\
\hline
\end{tabular}


Table 5 Continued

Pearson's Correlation of minimum air temperature and SWE

\begin{tabular}{|c|c|c|c|c|c|c|}
\hline $\begin{array}{l}\text { Station } \\
\text { Name }\end{array}$ & & $\begin{array}{c}\text { Jan Min } \\
\text { AirTemp } \\
\text { vs Feb } \\
\text { SWE }\end{array}$ & $\begin{array}{c}\text { Feb Min } \\
\text { AirTemp } \\
\text { vs Mar } \\
\text { SWE }\end{array}$ & $\begin{array}{c}\text { Mar Min } \\
\text { AirTemp } \\
\text { vs Apr } \\
\text { SWE }\end{array}$ & $\begin{array}{c}\text { Apr Min } \\
\text { AirTemp } \\
\text { vsMay } \\
\text { SWE }\end{array}$ & $\begin{array}{c}\text { May Min } \\
\text { AirTemp } \\
\text { vs June } \\
\text { SWE }\end{array}$ \\
\hline \multirow[t]{2}{*}{$\begin{array}{l}\text { Summit } \\
\text { Ranch } \\
(802)\end{array}$} & $\begin{array}{l}\text { Pearson } \\
\text { Correlation }\end{array}$ & 0.061 & -0.078 & 0.02 & -0.445 & 0 \\
\hline & Sig & 0.749 & 0.683 & 0.917 & 0.014 & 0.998 \\
\hline \multirow[t]{2}{*}{$\begin{array}{l}\text { North } \\
\text { Lost } \\
(669)\end{array}$} & $\begin{array}{l}\text { Pearson } \\
\text { Correlation }\end{array}$ & 0.089 & 0.113 & 0.037 & -0.574 & -0.184 \\
\hline & Sig & 0.645 & 0.552 & 0.844 & 0.001 & 0.349 \\
\hline \multirow[t]{2}{*}{$\begin{array}{l}\text { Phantom } \\
\text { Valley } \\
(688)\end{array}$} & $\begin{array}{l}\text { Pearson } \\
\text { Correlation }\end{array}$ & 0.128 & -0.278 & -0.035 & -0.078 & -0.28 \\
\hline & Sig & 0.501 & 0.137 & 0.854 & 0.681 & 0.134 \\
\hline \multirow[t]{2}{*}{$\begin{array}{l}\text { Lynx } \\
\text { Pass } \\
(607)\end{array}$} & $\begin{array}{l}\text { Pearson } \\
\text { Correlation }\end{array}$ & 0.13 & 0.051 & 0.037 & -0.217 & 0.073 \\
\hline & Sig & 0.492 & 0.79 & 0.847 & 0.248 & 0.703 \\
\hline \multirow[t]{2}{*}{$\begin{array}{l}\text { Still } \\
\text { Water } \\
\text { Creek } \\
\text { (793) }\end{array}$} & $\begin{array}{l}\text { Pearson } \\
\text { Correlation }\end{array}$ & 0.019 & -0.238 & -0.004 & 0.066 & -0.462 \\
\hline & Sig & 0.922 & 0.206 & 0.982 & 0.728 & 0.015 \\
\hline \multirow[t]{2}{*}{$\begin{array}{l}\text { Nast } \\
\text { Lake } \\
(658)\end{array}$} & $\begin{array}{l}\text { Pearson } \\
\text { Correlation }\end{array}$ & -0.128 & -0.024 & -0.065 & 0.057 & 0.033 \\
\hline & Sig & 0.499 & 0.901 & 0.734 & 0.767 & 0.865 \\
\hline
\end{tabular}




\subsubsection{Pearson's Correlation for streamflow vs mean air temperature}

Only one stream gage (Colorado River near Kremmling) USGS \#9058000 showed a significant negative correlation with April streamflow vs March mean air temperature (r-value -0.479 (Table 6)). This stream gage is located at a height of 7,320 feet and captures a total drainage area of 2,379 square miles in the upper region of the Colorado Headwaters basin (figure 4). Other negative correlations are noted in Table 6 but they are not statistically significant $(<0.05)$ with r-values ranging from -0.012 - $0.321)$. 


\section{Figure 4}

Location of Stream gage stations located in the study area

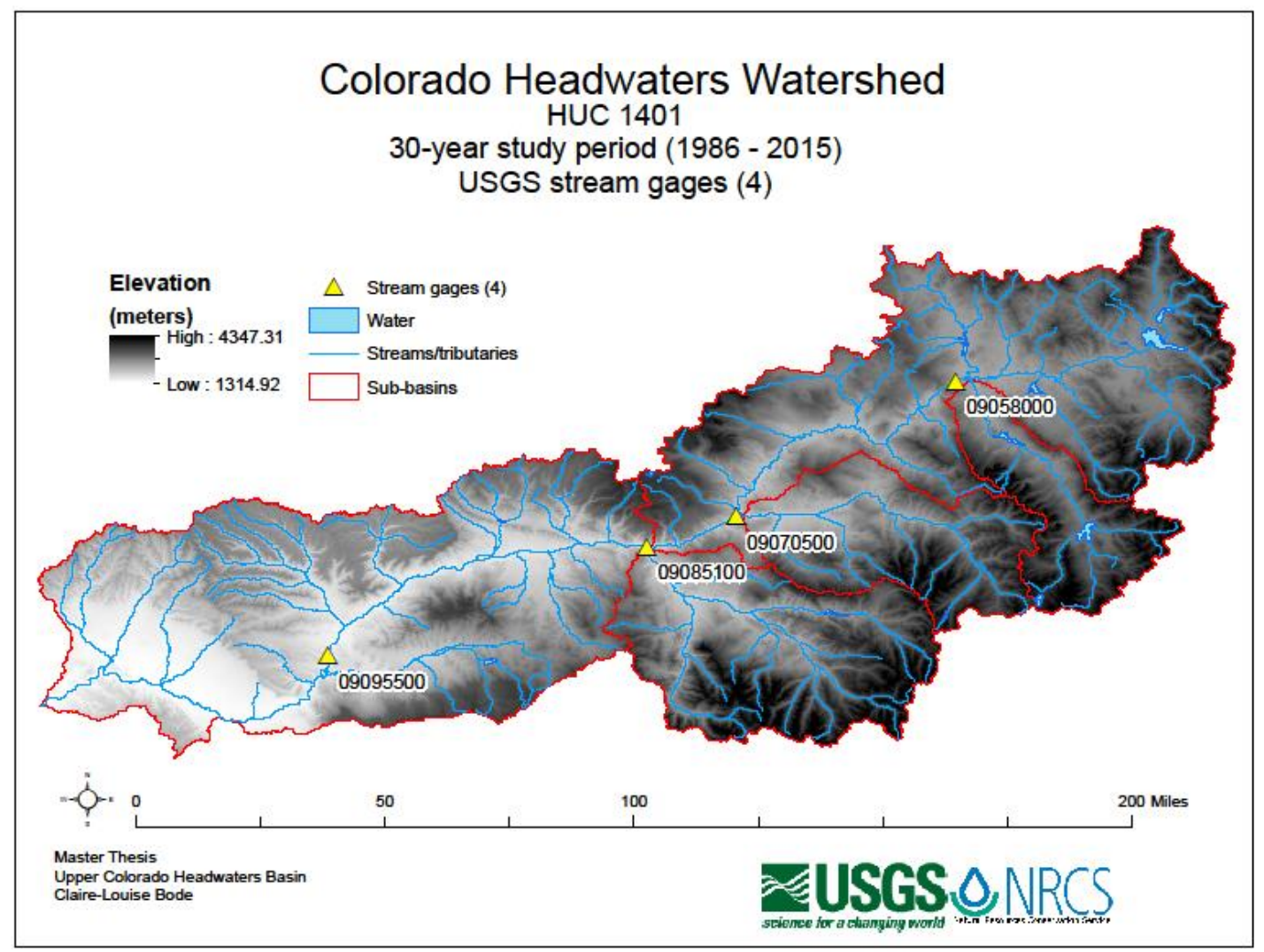


Table 6

Pearson's Correlation of Streamflow vs Mean Air Temperature

\begin{tabular}{|c|c|c|c|c|c|c|c|c|}
\hline $\begin{array}{c}\text { Stream } \\
\text { gauge } \\
\text { number }\end{array}$ & Name & & $\begin{array}{c}\text { Jan MAT } \\
\text { with Feb } \\
\text { streamflow }\end{array}$ & $\begin{array}{c}\text { Feb MAT } \\
\text { with Mar } \\
\text { streamflow }\end{array}$ & $\begin{array}{c}\text { Mar MAT } \\
\text { with Apr } \\
\text { streamflow }\end{array}$ & $\begin{array}{c}\text { Apr MAT } \\
\text { with May } \\
\text { streamflow }\end{array}$ & $\begin{array}{c}\text { May MAT } \\
\text { with Jun } \\
\text { streamflow }\end{array}$ & $\begin{array}{c}\text { June MAT } \\
\text { with Jul } \\
\text { streamflow }\end{array}$ \\
\hline & $\begin{array}{c}\text { Colorado River } \\
\text { near }\end{array}$ & Pearson & & & & & & \\
\hline 9058000 & Kremmling & Corr & -0.071 & 0.159 & -0.479 & -0.096 & 0.13 & 0.011 \\
\hline & & Sig & 0.714 & 0.409 & 0.009 & 0.62 & 0.508 & 0.955 \\
\hline & Colorado River & Pearson & & & & & & \\
\hline 9070500 & near Dotsero & Corr & 0.09 & -0.012 & -0.133 & -0.026 & -0.321 & -0.305 \\
\hline & & Sig & 0.635 & 0.949 & 0.485 & 0.893 & 0.083 & 0.101 \\
\hline & $\begin{array}{c}\text { Colorado } \\
\text { below }\end{array}$ & Pearson & & & & & & \\
\hline 9085100 & Glenwood & Corr & 0.059 & 0.04 & -0.129 & 0.078 & -0.186 & -0.244 \\
\hline & & Sig & 0.761 & 0.837 & 0.504 & 0.686 & 0.335 & 0.203 \\
\hline & Colorado near & Pearson & & & & & & \\
\hline 9095500 & Cameo & Corr & 0.092 & -0.041 & -0.15 & -0.88 & -0.17 & -0.08 \\
\hline & & Sig & 0.629 & 0.829 & 0.428 & 0.642 & 0.369 & 0.675 \\
\hline
\end{tabular}




\subsubsection{Pearson's Correlation for streamflow vs minimum air temperature}

The stream gage with the most negative correlations from January to May (rvalues ranging from -0.142 - -0.288) was (Colorado near Kremmling) USGS \#9058000, but none of these correlations were statistically significant $(<0.05$ (Table 7$))$. This stream gage is located at a height of 7,320 feet and captures a total drainage area of 2,379 square miles in the upper region of the Colorado Headwaters basin.

Stream gage (Colorado near Dotsero) USGS \#9070500 displayed negative correlations for May minimum temperature vs June streamflow (r-value -0.12 (Table 7)) but is not statistically significant $(<0.05)$. There are statistically significant values in the January minimum air temperature vs Feb streamflow and April minimum air temperature vs May streamflow but they did not have a negative correlation (r-values $-0.376-0.425$ (Table 7)). Stream gage 9070500 is located at 6,130 feet and has a total drainage area of 4,390 square miles. Stream gage \#9085100 (Colorado below Glenwood) displays a negative correlation (r-values between -0.009 - -0.098 (Table7)) but has no statistical significance values below 0.05 . This stream gage is located near Glenwood and has a total drainage area of 6,014 square miles and is 5,721 feet above sea-level. The last stream gage in the Colorado Headwaters Basin is (Colorado near Cameo) USGS \#9095500 and this gage displays no negative correlation over the January through June streamflow vs minimum air temperature. It does show a significance value of 0.025 in the April minimum air temperature vs May streamflow (Table 7). The gage is located near the end of the basin at 4,814 feet above sea level and captures a total drainage area of 7,986 square miles. 
Table 7

Pearson's Correlation of Streamflow vs Minimum Air Temperature

\begin{tabular}{|c|c|c|c|c|c|c|c|c|}
\hline $\begin{array}{c}\text { Stream } \\
\text { gauge } \\
\text { number }\end{array}$ & Name & & $\begin{array}{c}\text { Jan } \\
\text { MinAT } \\
\text { with Feb } \\
\text { streamflow } \\
\end{array}$ & $\begin{array}{c}\text { Feb } \\
\text { MinAT } \\
\text { with Mar } \\
\text { streamflow } \\
\end{array}$ & $\begin{array}{c}\text { Mar } \\
\text { MinAT } \\
\text { with Apr } \\
\text { streamflow }\end{array}$ & $\begin{array}{c}\text { Apr } \\
\text { MinAT } \\
\text { with May } \\
\text { streamflow }\end{array}$ & $\begin{array}{c}\text { May } \\
\text { MinAT } \\
\text { with Jun } \\
\text { streamflow }\end{array}$ & $\begin{array}{c}\text { June } \\
\text { MinAT } \\
\text { with Jul } \\
\text { streamflow }\end{array}$ \\
\hline \multirow{4}{*}{9058000} & $\begin{array}{c}\text { Colorado River } \\
\text { near }\end{array}$ & Pearson & & & & & & \\
\hline & Kremmling & Corr & -0.142 & -0.164 & -0.288 & -0.203 & -0.215 & 0.104 \\
\hline & & Sig & 0.47 & 0.395 & 0.129 & 0.292 & 0.262 & 0.59 \\
\hline & & $\mathrm{N}$ & 28 & 29 & 29 & 29 & 29 & 29 \\
\hline \multirow[t]{3}{*}{9070500} & $\begin{array}{l}\text { Colorado River } \\
\text { near Dotsero }\end{array}$ & $\begin{array}{l}\text { Pearson } \\
\text { Corr }\end{array}$ & 0.376 & 0.022 & 0.296 & 0.452 & -0.012 & 0.281 \\
\hline & & Sig & 0.044 & 0.91 & 0.112 & 0.012 & 0.95 & 0.132 \\
\hline & & $\mathrm{N}$ & 29 & 30 & 30 & 30 & 30 & 30 \\
\hline \multirow{4}{*}{9085100} & Colorado below & Pearson & & & & & & \\
\hline & Glenwood & Corr & -0.009 & 0.123 & -0.098 & 0.218 & -0.076 & -0.09 \\
\hline & & Sig & 0.96 & 0.516 & 0.608 & 0.248 & 0.692 & 0.635 \\
\hline & & $\mathrm{N}$ & 30 & 30 & 30 & 30 & 30 & 30 \\
\hline \multirow{4}{*}{9095500} & Colorado near & Pearson & & & & & & \\
\hline & Cameo & Corr & 0.25 & 0.332 & 0.177 & 0.408 & 0.001 & 0.008 \\
\hline & & Sig & 0.182 & 0.073 & 0.349 & 0.025 & 0.997 & 0.968 \\
\hline & & $\mathrm{N}$ & 30 & 30 & 30 & 30 & 30 & 30 \\
\hline
\end{tabular}




\subsection{Runs Test}

\subsubsection{Runs Tests of SWE, Mean Air Temperature and Minimum Temperature}

The runs test tests for the presence of randomness or stationarity in the time series data. The z-value (runs test statistic) that is produced, determines if any of the datasets display a switch from stationary to non-stationary patterns over time (30-year period from 1986 to 2015). A negative z-value highlights that there is a downward development of a non-stationary trend over the time period, while a positive z-value highlights an upwards development. Either would suggest that the regional climate and snowpack is shifting from a more predictable stationary to a less predictable non-stationary behavior.

\subsubsection{SWE}

Above 10,000 feet $(3,048 \mathrm{~m})$ -

Only SNOTEL stations 531 (Hoosiers Pass) and 542 (Independence Pass) displayed both negative z-values and were found to be statistically significant in the months of February and March (z-values ranging from -0.162 - -2.415). Two SNOTEL stations, 531 (Hoosier Pass) and 622 (Mesa Lake), display negative z-values ranging from $-0.222--2.415$ (Table A1) for all months January to June but not all of these were statistically significant over the study period. 10 out of the 11 SNOTEL stations located above 10,000 feet (figure 2) displayed negative z-values over multiple months over the study period (z-values ranging from $-0.088-2.415$, Table A1).

Below 10,000 feet $(3,048 \mathrm{~m})$ - 
There are no SNOTEL stations that were statistically significant and displayed a negative $\mathrm{z}$-value for the entire study period. All 9 SNOTEL stations located under 10,000 feet (figure 3) did have between one and four months of negative z-values ranging from 0.107 - -1.552 (Table A1).

\subsubsection{Mean Air Temperature}

Above 10,000 feet (3,048 m) -

4 SNOTEL stations, 335 (Berthoud Summit), 505 (Grizzly Peak), 542

(Independence Pass) and 415 (Copper Mountain), displayed both negative z-values that were statistically significant for the months of January and June for the entire study period. Three SNOTEL stations, 485 (Freemont Pass), 531 (Hoosier Pass) and 335 (Berthoud Summit), displayed negative z-values ranging from -0.323 - -2.287 (Table A1) for all months January to June but not all of these were statistically significant over the study period. All 11 SNOTEL stations located above 10,000 feet (figure 2) displayed negative $\mathrm{z}$-values for three or more months over the study period (z-values ranging from 0.062 - -2.287, Table A1).

Below 10,000 feet $(3,048 \mathrm{~m})$ -

Two SNOTEL stations, 618 (McClure Pass) and 802 (Summit Ranch), displayed a statistically significant negative z-values of -1.981 and -2.402 (Table A1) for the months of February and January for the period of the study. All 9 SNOTEL stations (figure 3) had between two and five months of negative z-values (ranging from -0.088 - 2.402, Table A1) for the study period but are not statistically significant. 


\subsubsection{Minimum Temperature}

Above 10,000 feet $(3,048 \mathrm{~m})$ -

SNOTEL station 335 (Berthoud Summit) was the only station to display a negative z-value of -2.681 (Table A1) that was statistically significant in the month of June for the entire study period. All 11 SNOTEL stations located above 10,000 feet (figure 2) displayed negative $\mathrm{z}$-values ranging from -0.041 - -1.655 (Table A1) for at least one month during the entire study period.

Below 10,000 feet $(3,048 \mathrm{~m})$ -

Only 2 SNOTEL stations, 869 (Willow Creek Pass) and 618 (McClure Pass), display statistically significant negative z-values of -2.775 and -2.043 (Table A1) for the months of January and May in the study period. All 9 other SNOTEL stations located below 10,000 feet (figure 3) were not statistically significant but had negative $\mathrm{z}$-values ranging from $-0.088--2.775$ for three to six months of the study period. SNOTEL station 658 (Nast Lake) was the only station to display negative z-values for all months January to June in the study period (Table A1).

\subsubsection{Runs Test of Stream Gages}

A runs test performed for the stream gages in the Colorado Headwaters Basin each monthly variable at each of the 4 stream gage stations (figure 4).

Only stream gage station 9095500 (Colorado River near Cameo) displayed a statistically significant z-value of -2.36 (Table 8 ) in the month of February for the entire study record. Stream gage station 9095500 (Colorado near Cameo) is located at 4,814 feet $(1,467$ meters) above sea level and has a drainage area of 7,986 square miles. All 4 stream gage 
stations, 9095500 (Colorado River near Cameo), 9085100 (Colorado River below Glenwood Springs), 9070500 (Colorado near Dotsero) and 9058000 (Colorado River near Kremmling) display negative z-values that range from -.349 - -2.36 (Table 8) for one or more months throughout the entire study period. As the elevation decreases between each stream gage station located in the Colorado Headwaters Basin there is an increase in the number of months that display a negative z-values between the highest elevations to the lowest elevation. Stream gage station 9058000 (Colorado River near Kremmling), which has the highest elevation of all 4 stations used in the study $(7,320$ feet $)$ only has a negative z-value of -1.737 in the month of February. Stream gage station 9095500 (Colorado near Cameo), which is the lowest station used in the study (4,814 feet) has 10 months excluding April and May (z-values of 0, Table 8) that display negative z-values ($0.349--1.512$, Table 8 of which February is the only month that is statistically significant for the entire study period.

\subsection{Linear Regression}

\subsubsection{Linear Regression of SWE, mean air temperature and minimum air temperature}

The linear regression results provide the necessary values for the linear regression equation. The B-value for the independent variable (water year) displays the direction of the trend. If the B-value displays a negative value then there is evidence of a downward trend over time and vice versa. The p-value (significance value) then determines whether the B-value signifies a statistically significant trend. 


\subsubsection{SWE}

Above 11,000 feet $(3,048 \mathrm{~m})$ -

A negative trend is observed for SNOTEL station 531 (Hoosier Pass) in January and May with B-values ranging from -0.021 - -0.264 (Table A1), indicating that a declining trend in the SWE data is captured for these stations occurring over the study period. However they are not statistically significant. Another further single SNOTEL station 335 (Berthoud Summit) displays negative trends for January and April (B-values ranging from $-0.096--0.144$ (Table A1). Only two SNOTEL stations above 11,000 feet display a declining trend in their SWE totals. Although not statistically significant they are important to include in this study as they do exhibit trends that are declining /near negative trends.

Above 10,000 feet (3048m) and below 11,000 feet (3,352m) -

SNOTEL station 345 (Bison Lake), 842 (Vail Mountain) and 622 (Mesa Lake, figure 5) display a negative trend over all months from January to June for the study period. The B-values range from -0.08 - -0.511 (Table A1). SNOTEL station 345 (Bison Lake) displays negative trends that are extremely close to the $<0.05$ significance level for the months of April to June. SNOTEL station 737 (Schofield Pass) also displays a negative trend in the months of January and March through to June (B-values ranging from $-0.022--0.165$ (Table A1). SNOTEL station 565 (Lake Irene) and 869 (Willow Creek Pass) display similar trends to SNOTEL station 737 as it has recorded negative trends in the months of January through May with B-values of $-0.079--0.33$ (Table A1). 
Lastly, SNOTEL station 542 (Independence Pass) records it's only negative B-value (.0 .82 (Table A1)) trend in the month of May.

A total number of 9 SNOTEL stations above 10,000 feet (figure 2) have recorded negative B-value trends in their study period records for monthly SWE totals. Although they are not statistically significant they are important to include in this study as they do exhibit trends that are declining and have near negative trends.

Below 10,000 feet (3048 m) -

SNOTEL stations 556 (Kiln, figure 8) and 618 (McClure) display a negative trend over the months of January and April through June with B-values ranging from -0.067 - 0.608 (Table A1). A further SNOTEL 869 (Willow Creek Pass) displays a negative trend over all months from January to May for the study period. The B-values range from 0.023 - -0.302 (Table A1). SNOTEL stations 802 (Summit Ranch), 669 (North Lost Trail) and 688 (Phantom Valley) all record multiple months of a negative correlation (Bvalues ranging from $-0.084--1.835$ (Table A1)). Although they are not all statistically significant they are all recording a decline over the study period. There are a total of 6 SNOTEL stations above 9,000 feet that have negative B-values recorded for all or some of their monthly SWE totals.

All three SNOTEL stations 607 (Lynx Pass), 793 (Still Water Creek) and 658 (Nast Lake) have negative trends for multiple months within their SWE data records for the study period. Their B-values range from $-0.03--6.322$ (Table A1). There are a total of 3 SNOTEL stations above 8,000 feet that have recorded negative B-value trends over 
the study period (figure 3). Although they are not all statistically significant they are all recording a decline over the study period.

Overall there are a total number of 9 SNOTEL stations that record negative Bvalues for various months within the study records. Although they are not all statistically significant they are all recording a decline over the study period. The entire Colorado Headwaters Basin study area records a total number of 18 out of the 20 SNOTEL stations included in this study to have negative correlations in their SWE records for the study period from 1986 to 2015 (figure 1). The results imply that there seems to be less SWE during the cold months leading into the spring and summer season. With less SWE around April 1 of the season, it is likely that there will be less snowmelt for the preceding seasons from these higher elevation snowpacks as well as the ones that are lower in elevation and have more variability with the season changes.

\subsubsection{Mean Air Temperature}

When looking at the air temperature linear regression results, it is important to note that trends in a positive direction indicate an increase in air temperature at the SNOTEL station. Any positive beta trends that are statistically significant support the findings that SWE is dominated by negative trends. Where there is an increase in air temperature there should be a decline in SWE over the same time period.

Above 10,000 feet (3048 m) -

2 SNOTEL stations 335 (Berthoud Summit) and 542 (Independence Pass) display a significantly strong positive trend over all months (January to June), with B-values ranging from $1.254-1.968$ (Table A1). All 11 SNOTEL stations that are located above 
10,000 feet namely 485 (Freemont Pass), 531 (Hoosier Pass), 335 (Berthoud Summit), 505 (Grizzly Peak), 345 (Bison Lake), 737 (Schofield Pass), 565 (Lake Irene), 542 (Independence Pass), 415 (Copper Mountain), 842 (Vail Mountain) and 662 (Mesa Lake, figure 6) all display strong positive trends over the period of their record with B-values ranging from $0.051-1.982$ (Table A1). Over these 11 SNOTEL stations a clear positive B trend is seen over the 30-year record (1986 to 2015), with most of the trends being statistically significant (figure 2).

Below 10,000 feet (3048 m) -

SNOTEL station 618 (McClure) displays a strong significant trend over all months (January to June), with B-values ranging from 1.059-1.469 (Table A1).It is the only station to record statistically significant positive B-values for all the months in the study record (1986 to 2015). All 8 other SNOTEL stations below 10,000 feet record positive trends, such as SNOTEL station 556 (Kiln, figure 9) (B-values ranging from 0.345 - 1.654 (Table A1)). Most stations below 10,000 feet (figure 3) only have between 1 and 3 months that record significant positive B-value trends, with the most occurring in January and June followed by March and May (Table A1).

Overall for the mean air temperature records all SNOTEL stations display positive B-value trends over the course of the study period for the Colorado Headwaters Basin. This supports the findings that SWE trends are dominated by the negative trends, as when the data indicated that there is a warming trend in the air temperature there is a decline in the SWE. 


\subsubsection{Minimum Air Temperature}

Above 10,000 feet (3048 m) -

7 SNOTEL stations 531 (Hoosier Pass), 335 (Berthoud Summit), 505 (Grizzly Peak), 345 (Bison Lake), 565 (Lake Irene), 542 (Independence Pass) and 415 (Copper Mountain) all display strong significant positive trends with B-values ranging from 0.059 - 1.462 (Table A1). Although all 11 SNOTEL stations located above 10,000 feet (figure

2) display strong positive B-value trends, only 7 SNOTEL stations display this positive trend over all months (January to June) such as SNOTEL station 622 (Mesa Lakes, figure 7). All SNOTEL stations record a positive increase in B-values in the months of March, April and June, which is indicative of a warming trend in the winter and spring season within the geographical study area of the Colorado Headwaters Basin.

Below 10,000 feet (3048 m) -

7 SNOTEL stations (figure 3) have at least one or more months that record a strong positive trend significance with B-values ranging from $0.016-1.337$ (Table A1), such as SNOTEL station 556 (Kiln, figure 10). SNOTEL station 658 (Nast Lake) displays a strong positive trend that is significant $(<0.05)$ over the months of March through to June (B-values ranging from $0.196-0.645$ (Table A1)). SNOTEL stations 618 (McClure), 688 (Phantom Valley) and 793 (Still Water Creek) all have two months of significant positive trends in their records, whereas SNOTEL stations 556 (Kiln), 869 (Willow Creek Pass), 802 (Summit Ranch) and 669 (North Lost Trail) only have a single month of strong positive significance recorded (Table A1). 
Overall, there is not a very high presence in the data of a significant trend detected with the minimum air temperature, all 20 SNOTEL stations do experience a positive increase in their trends over the study period from 1986 - 2015 (Table A1).

The positive trends detected in the B-values, even if not at the $95 \%$ confidence level still support the findings that the SWE is dominated by negative trends. The data suggests that there are more significant positive trends present in the mean air temperature than with the minimum air temperature within the geographical study region which can be attributed to the minimum air temperature only relating to one day of the month whereas the mean air temperature takes all the days of the month into consideration (Table A1). 


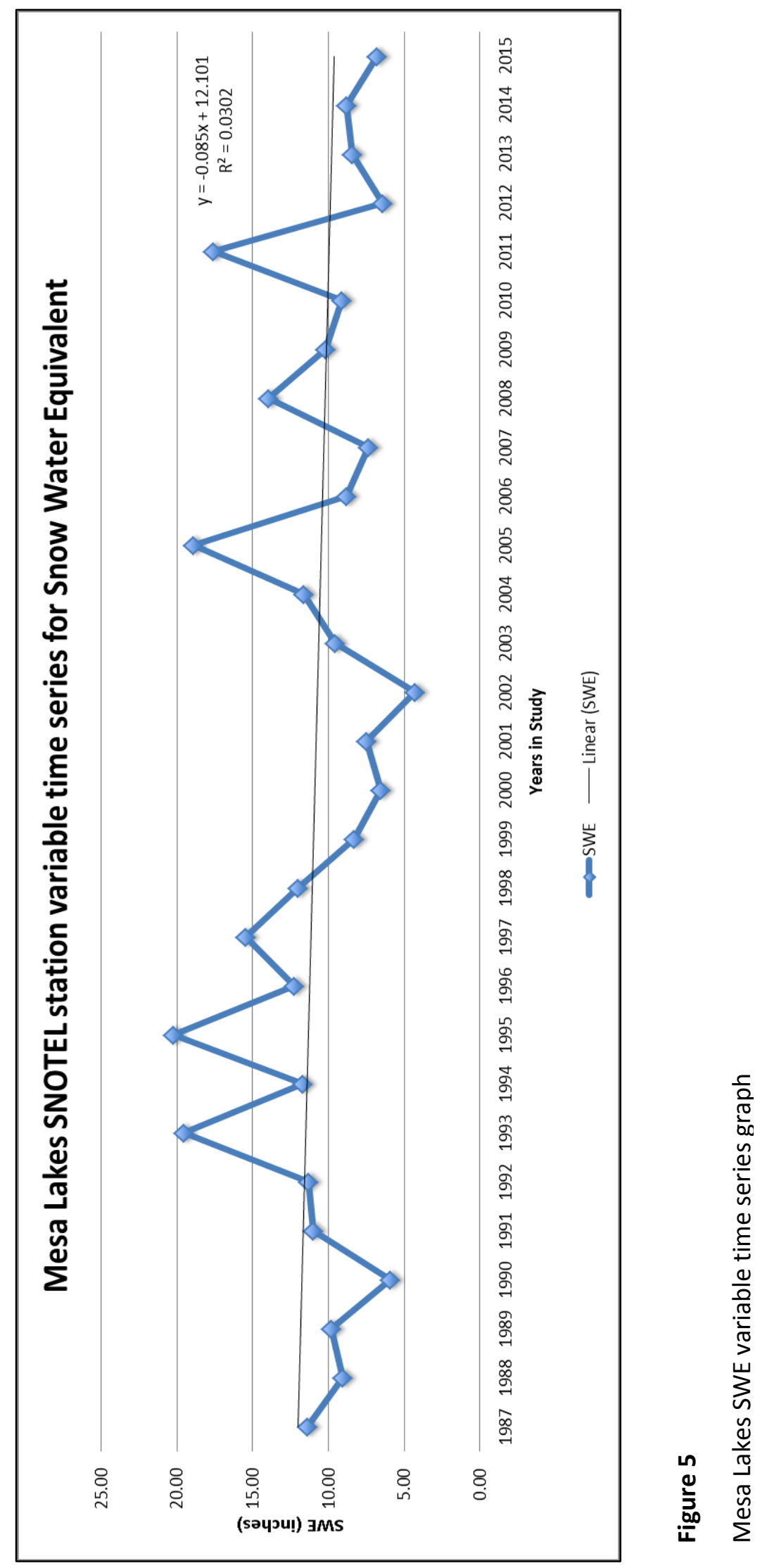




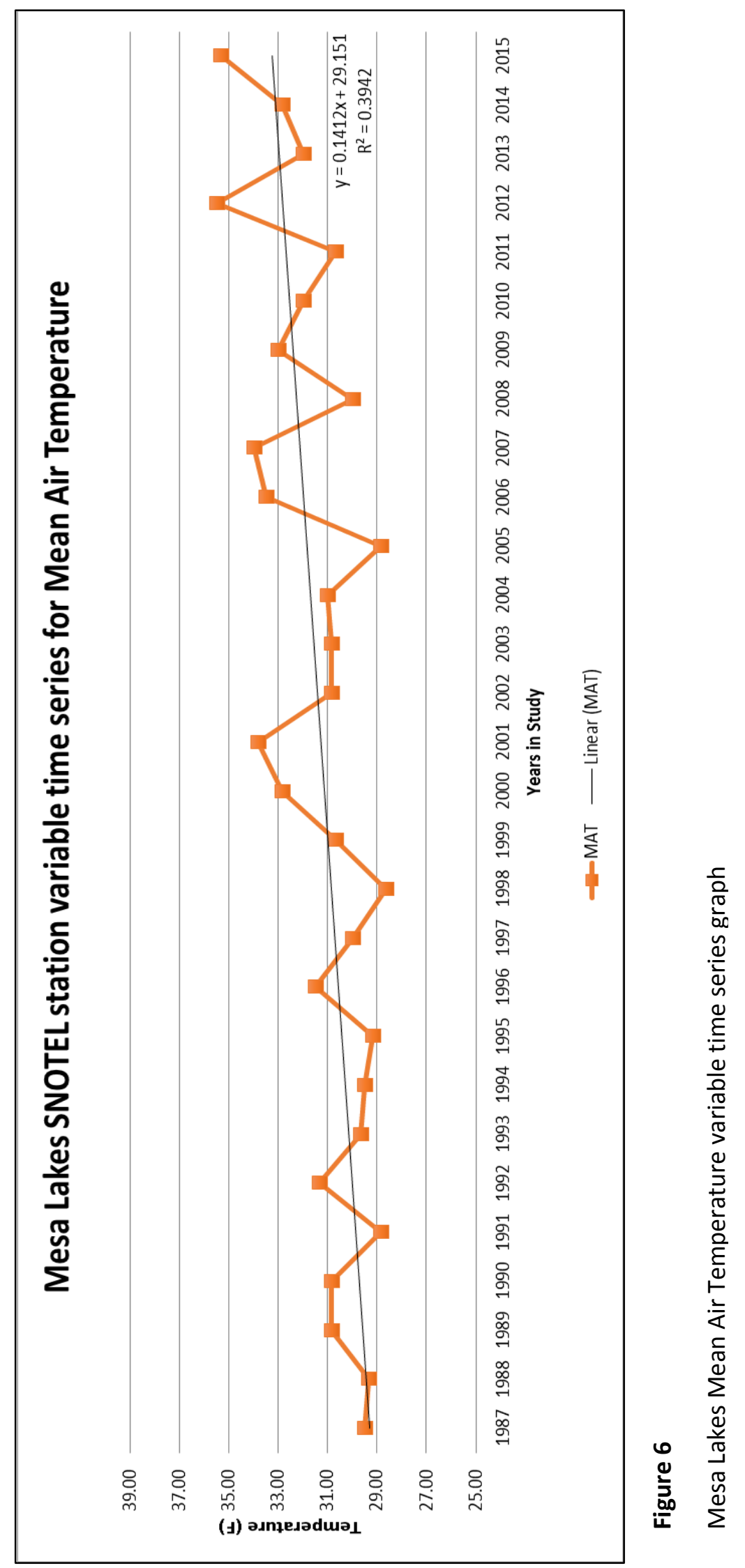




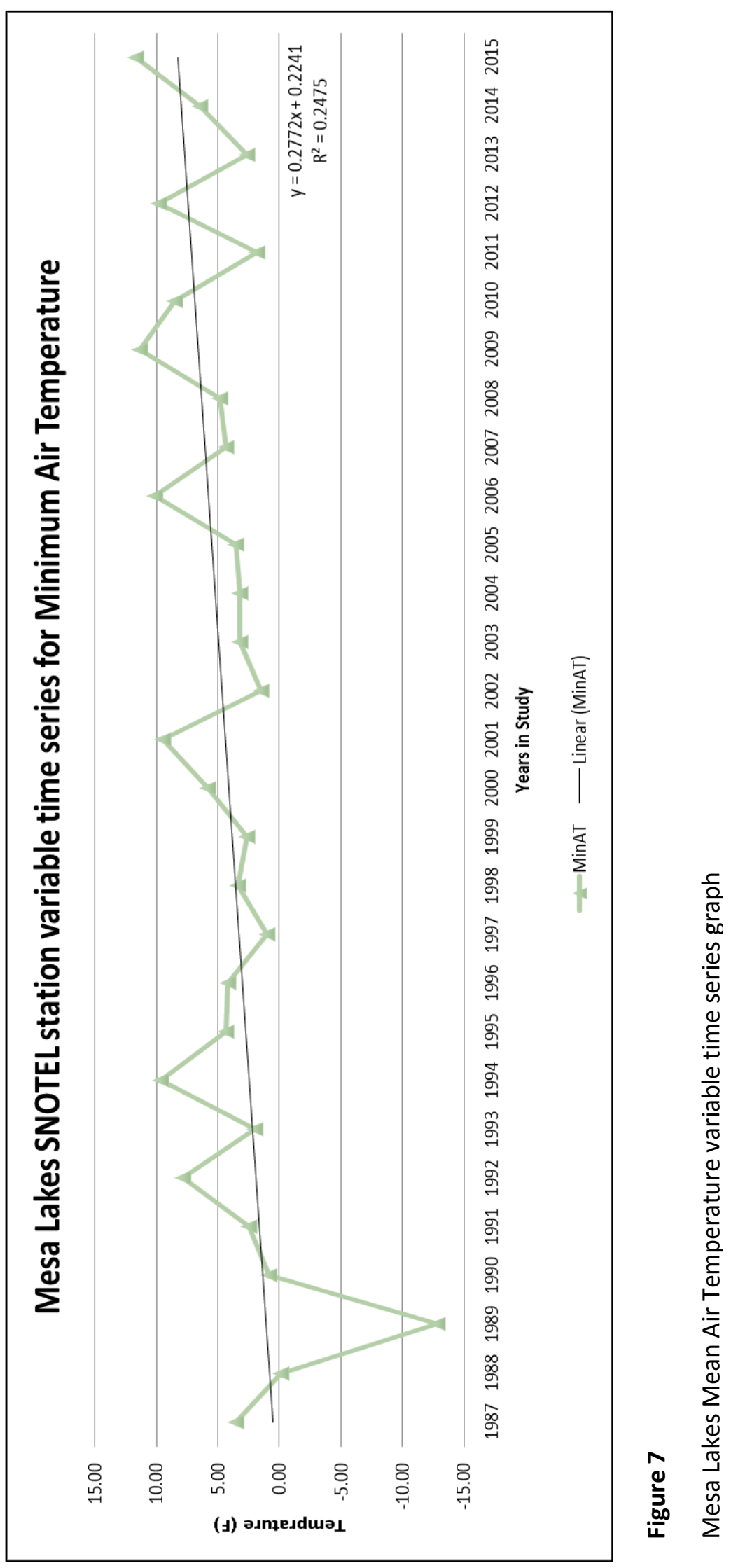




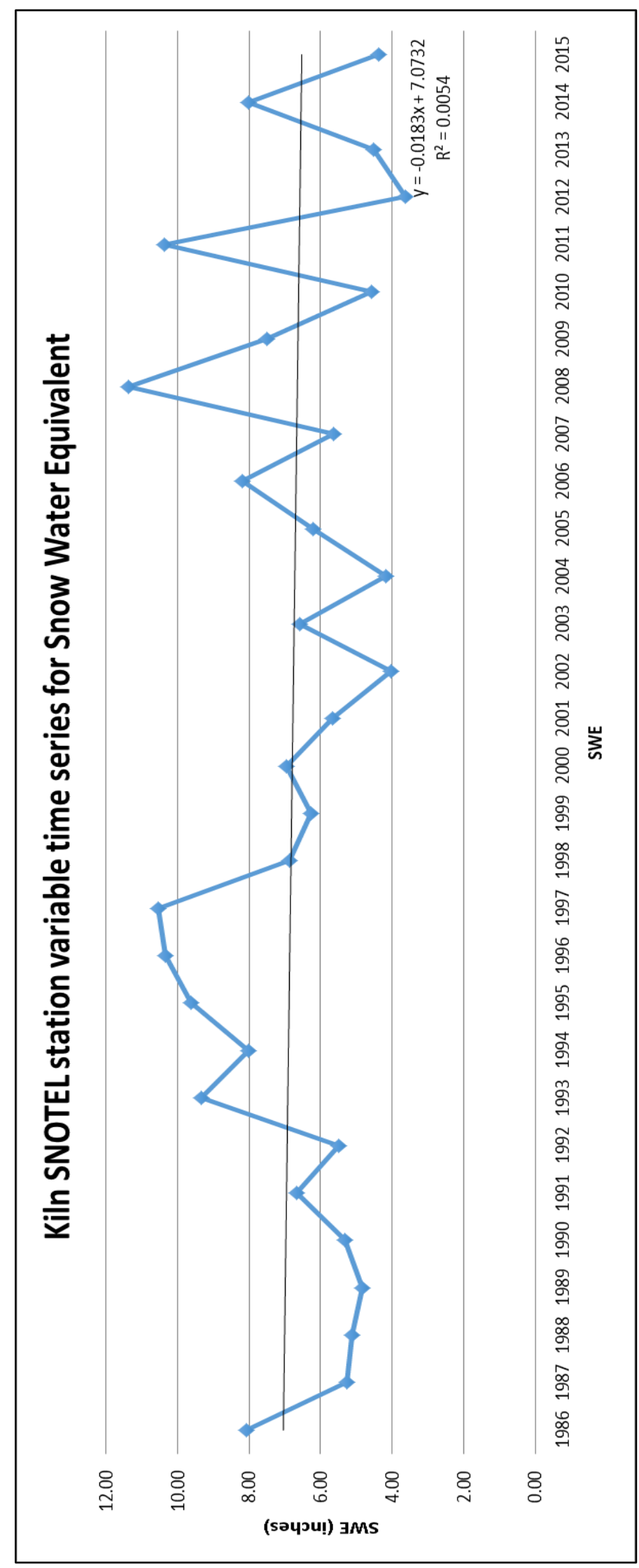

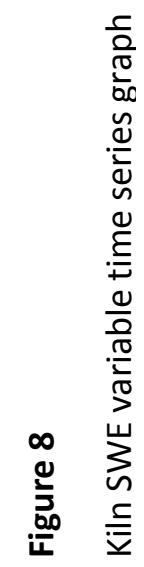




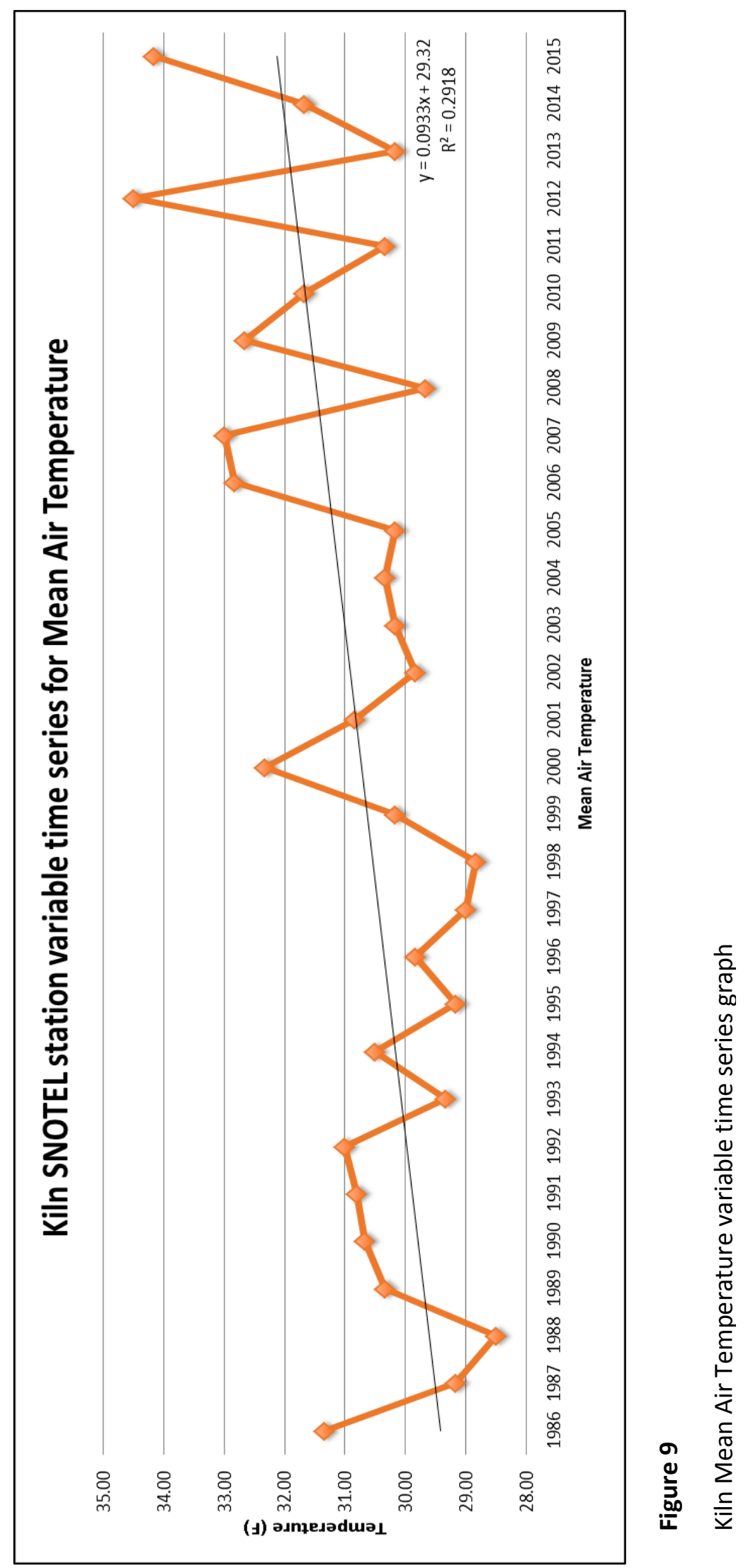




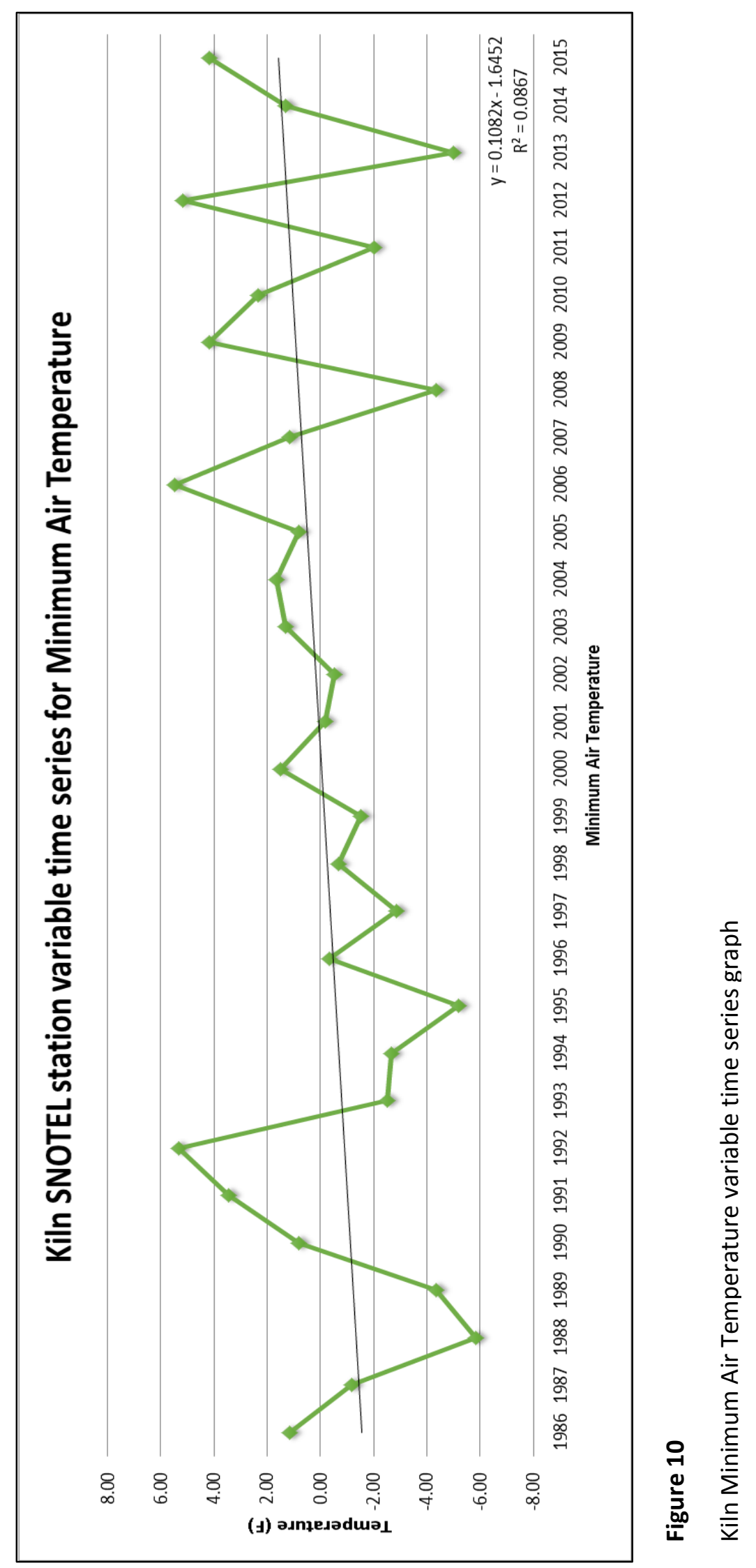




\subsubsection{Stream gage linear regression}

All 4-stream gage locations (figure 4) that were chosen for this study display negative trends in their B-values for the months November through April for the records of the study period. These B-values range from $-0.036--0.721$ (Table 8 ). The only stream gage that displays a statistically significant negative linear regression for the months of November and December is 9085100 (Colorado near Glenwood Spring), which is located at 5,721 feet above sea level and has a drainage area of 6,014 square miles (Figure 1).

The results of the linear regression test indicate that there may be an impact on stream flow from dams located upstream, which impact the discharge release timing after the warmer weather. There are 50 documented dams within the Colorado Headwaters Basin (Figure 11), which are most likely being used to store the snowmelt for controlled release timing during the warmer months. 


\section{Figure 11}

Location of Dams in the study area

\section{Colorado Headwaters Basin \\ Dams}

within the HUC 1401 basin

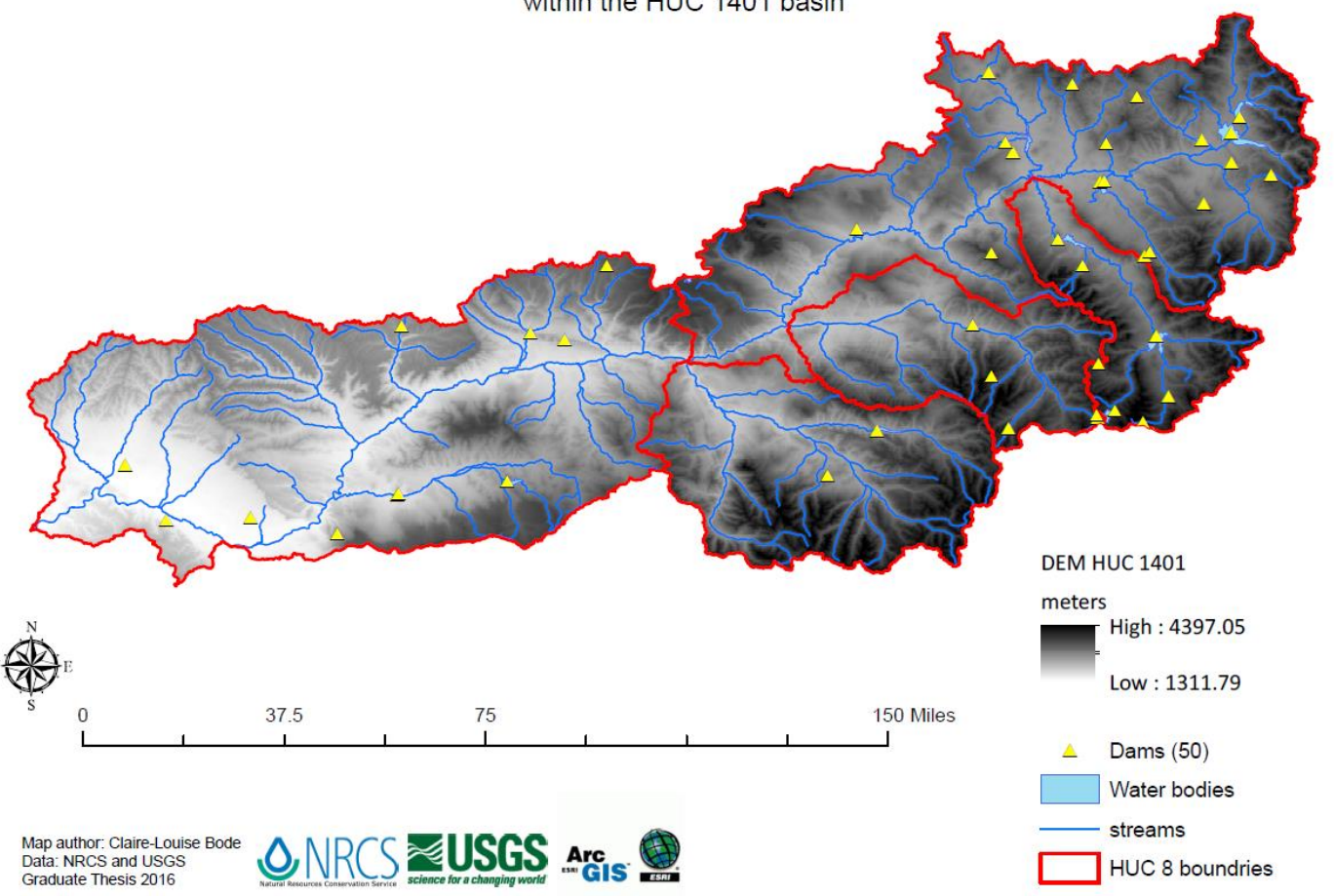




\section{Table 8}

Linear Regression and Runs Test for Stream gages in the Upper Colorado Region

\begin{tabular}{|c|c|c|c|c|c|c|c|c|c|c|c|c|c|c|c|c|c|}
\hline ID & Stream gage & $\begin{array}{c}\text { Height } \\
\text { (feet) }\end{array}$ & $\begin{array}{c}\text { dran/ } \\
\text { area }\end{array}$ & & & Jan & Feb & Mar & Apr & May & Jun & Jul & Aug & Sep & Oct & Nov & Dec \\
\hline \multirow[t]{5}{*}{9095500} & Colorado & 4,814 & 7,986 & liner & adj r2 & 0.039 & 0.025 & 0.007 & -0.016 & -0.035 & -0.011 & -0.028 & -0.035 & -0.011 & 0 & 0.034 & 0.032 \\
\hline & River & & & regression & sig & 0.151 & 0.197 & 0.282 & 0.463 & 0.928 & 0.412 & 0.66 & 0.938 & 0.417 & 0.323 & 0.34 & 0.352 \\
\hline & Near & & & & $\mathrm{B}$ & -0.255 & -0.191 & -0.122 & -0.036 & 0.002 & 0.008 & 0.007 & 0.005 & 0.096 & 0.109 & -0.149 & -0.159 \\
\hline & Cameo & & & runs test & z-score & -0.908 & -2.36 & -1.512 & 0 & 0 & -1.512 & -0.846 & -0.976 & -0.349 & -1.508 & -1.393 & -0.751 \\
\hline & & & & & sig & 0.364 & 0.018 & 0.131 & 1 & 1 & 0.131 & 0.398 & 0.329 & 0.727 & 0.132 & 0.164 & 0.453 \\
\hline \multirow[t]{5}{*}{9085100} & Colorado & 5,721 & 6,014 & liner & adj $\mathrm{r} 2$ & 0.038 & 0.027 & -0.007 & -0.028 & -0.029 & -0.003 & -0.029 & -0.035 & 0.1 & -0.014 & 0.118 & 0.106 \\
\hline & Below & & & regression & sig & 0.154 & 0.191 & 0.377 & 0.657 & 0.669 & 0.349 & 0.682 & 0.887 & 0.267 & 0.443 & 0.036 & 0.044 \\
\hline & Glenwood- & & & & $\mathrm{B}$ & -0.318 & -0.26 & -0.123 & -0.028 & 0.01 & 0.011 & 0.007 & 0.01 & 0.157 & 0.104 & -0.272 & -0.315 \\
\hline & Springs & & & runs test & z-score & 0 & -1.737 & -1.737 & 0 & 0 & 0 & 0 & 0 & 0 & 0 & -1.737 & 1.704 \\
\hline & & & & & sig & 1 & 0.082 & 0.082 & 1 & 1 & 1 & 1 & 1 & 1 & 1 & 0.082 & 0.088 \\
\hline \multirow[t]{5}{*}{9070500} & Colorado & 6,130 & 4,390 & liner & adj r2 & 0.066 & 0.038 & 0.003 & -0.017 & -0.024 & -0.005 & -0.018 & -0.024 & 0.09 & 0.068 & 0.02 & 0.017 \\
\hline & River & & & regression & sig & 0.092 & 0.155 & 0.307 & 0.477 & 0.559 & 0.362 & 0.489 & 0.556 & 0.063 & 0.093 & 0.223 & 0.233 \\
\hline & Near & & & & B & -0.533 & -0.385 & -0.189 & -0.054 & 0.016 & 0.015 & 0.018 & 0.071 & 0.388 & 0.33 & -0.352 & -0.392 \\
\hline & Dotsero & & & runs test & z-score & 0 & -1.737 & -1.701 & 0 & 0 & 0 & 0 & -0.851 & 0 & 0 & -1.701 & -1.701 \\
\hline & & & & & sig & 1 & 0.082 & 0.089 & 1 & 1 & 1 & 1 & 0.395 & 1 & 1 & 0.089 & 0.089 \\
\hline \multirow[t]{5}{*}{9058000} & Colorado & 7,320 & 2,379 & liner & adj $\mathrm{r} 2$ & 0.056 & 0.007 & -0.002 & -0.004 & -0.015 & 0.049 & 0.02 & 0.03 & 0.241 & 0.105 & 0.043 & 0.053 \\
\hline & River & & & regression & sig & 0.11 & 0.279 & 0.341 & 0.358 & 0.457 & 0.126 & 0.218 & 0.178 & 0.003 & 0.048 & 0.144 & 0.121 \\
\hline & Near & & & & B & -0.761 & -0.466 & -0.255 & -0.099 & 0.035 & 0.042 & 0.056 & 0.297 & 0.781 & 0.516 & -0.721 & -0.713 \\
\hline & Kremmling & & & runs test & z-score & 0 & -1.737 & 0 & 0 & 0 & 0 & 0 & 0.401 & 0 & 0 & 0.132 & 0 \\
\hline & & & & & sig & 1 & 0.082 & 1 & 1 & 1 & 1 & 1 & 0.688 & 1 & 1 & 0.895 & 1 \\
\hline
\end{tabular}




\subsection{SUMMARY AND CONCLUSION}

Reductions in mountain snowpack, SWE and changes in snowmelt dominated streamflow timing from higher elevations are of considerable concern in regions where the human water demand already equals or exceeds the water supply today. The timing, volume, and extent of mountain snowpack, and the associated snowmelt runoff, are intrinsically linked to seasonal climate variability and change.

The observed changes in SWE air temperature and streamflow show:

- That there has been a general decrease in the SWE and an increase in temperature for the 30-year study period.

- The greatest declining SWE trends and increasing temperature trends were noted above 10,000 feet.

- The biggest decline in SWE and largest temperature increase occurred at SNOTEL station 622 located above 10,000 feet (Mesa Lake, SWE b-value at -

0.511 (Table A1, figure 5), and mean air temperature b-value at 1.982 (Table A2, figure 6).

- All stream gages showed multiple declines in streamflow for the months November through to April (Table 8, figure 4).

Although SWE and streamflow studies have not been performed for all the mountain ranges and high elevation snowpacks in the region, the available data used for this study suggests that the high elevation snowpacks are reacting to increasing 
temperature trends and as a result there is a declining trend in SWE. In particular, there is evidence that the high elevation snowpacks are particularly sensitive to mean temperature-warming trends over the key snowpack accumulation months. The observed impact on the high altitude snowpacks from climate variability in the Colorado Headwaters Basin must be interpreted as a response to temperature change for any location.

These findings are consistent with Knowles et al (2006), in that there is a link between the decline in SWE and increase in temperature, which is changing the water output for the region that relies heavily on snowmelt as its main water resource. Furthermore, this is an indication of a shift from stationary to non-stationary behavior for the Colorado Headwaters Basin seen with the onset of snowmelt and mean air temperature changes (Milly et al 2008). Variability in the climate of the Colorado Headwaters Basin is reproduced in the variability of SWE and onset of snowmelt in the high altitude regions (IPCC 2013).

The climate shift is disrupting the normal variation of snowmelt and its subsequent streamflow trends as spring SWE has declined and there is an onset of snowmelt occurring earlier in the year (Cayan 1996, Nijssen et al 2001), which is leading to a reduction in natural storage of water for the Western United States. These results correspond with previous studies that suggest that these changes are most felt where the mean winter temperatures are rising yet are not very far below freezing (Stewart et al 2005, Knowles et al 2006, Mote 2006). The last 30 yeas of recent observations in the Colorado Headwaters Basin document the changes in the early onset of snowmelt in the region and further indicate that the high altitude snowpacks may now be susceptible to 
the warming climate (Clow 2010) due to the reduced SWE and warming winter and spring season temperatures.

Not all data collected agreed with the general findings. Potential reasons responsible for these disagreements could be due to local temperature or SWE accumulations differing from site to site, technical errors, changes in instruments or a region within the Colorado Headwaters Basin that is possibly under the influence of a different climate response to atmospheric circulations.

Suggestions for further research based upon the findings in this study include an in-depth study on the other smaller watershed basins in the surrounding regions to see if the climate trends are varying across adjacent watersheds at different rates. Another longer time period study should be conducted to further distinguish natural variability from long-term climate changes on all spatial and temporal scales. The regional sensitivity of the mountain snowpack and melt runoff system to warming and the past and future occurrence of precipitation regime shifts are both important areas of research which have not systematically been explored for many key mountain ranges worldwide, often because of a lack of data. There is a need to investigate these regions further as a result. 


\section{REFERENCES}

Barnett, T., R. Malone, W. Pennell, D. Stammer, B. Semtner, and W. Washington. (2004). The effects of climate change on water resources in the west: Introduction and overview. Climatic Change (62): 1-11.

Barnett, T. P., and D. W. Price. (2009). Sustainable water deliveries from the Colorado River in a changing climate. PNAS. (106) $7334-7338$.

Bedford, D., A. Douglass. (2008). Changing Properties of Snowpack in the Great Salt Lake Basin, Western United States, from a 26-year SNOTEL Record. The Professional Geographer. (60) 347 - 386.

Cayan, D. R. (1996). Interannual climate variability and snowpack in the western United States. Journal of Climate (9): 928-948.

Cayan, D. R., S. A. Kammerdiener, M. D. Dettinger, J. M. Caprio, and D. H. Peterson. (2001). Changes in the onset of spring in the western United States. Bulletin of American Meteorology Society. (82): 399-415.

Christensen, N. S., A. W. Wood, N. Voisin, D. P. Lettenmaier, and R. N. Palmer. (2004) The effects of climate change on the hydrology and water resources of the Colorado River Basin. Climate Change. (62) 337 - 363

Clow, D. W. (2010). Changes in the Timing of Snowmelt and Streamflow in Colorado: A Response to Recent Warming. Journal of Climate. (23): 2293 - 2306.

Hartmann, D.L., A.M.G. Klein Tank, M. Rusticucci, L.V. Alexander, S. Brönnimann, Y . Charabi, F.J. Dentener, E.J. Dlugokencky, D.R. Easterling, A. Kaplan, B.J. Soden, P.W. Thorne, M. Wild and P.M. Zhai. (2013). Observations: Atmosphere and Surface. In: Climate Change 2013: The Physical Science Basis. Contribution of Working Group I to the Fifth Assessment Report of the Intergovernmental Panel on Climate Change [Stocker, T.F., D. Qin, G.-K. Plattner, M. Tignor, S.K. Allen, J. Boschung, A. Nauels, Y. Xia, V. Bex and P.M. Midgley (eds.)]. 
Cambridge University Press, Cambridge, United Kingdom and New York, NY, USA

Hamlet, A.F., P. W. Mote, M. P. Clark, and D. P. Lettenmaier. (2005). Effects of Tempreature and Precipitation Variability on Snowpack Trends in the Western United States. Journal of Climate. (18) 4545 - 4561.

Helsel, D. R., and R. M. Hirsch. (2002). Statistical methods in water resources. US Geological Survey: Reston, VA.

Hegerl, G.C., F. W. Zwiers, P. Braconnot, N.P. Gillett, Y. Luo, J.A. Marengo Orsini, N. Nicholls, J.E. Penner and P.A.Stott (2007) Understanding and Attributing Climate Change. In: Climate Change 2007: The Physical Science Basis. Contribution of Working Group I to the Fourth Assessment Report of the Intergovernmental Panel on Climate Change [Solomon, S., D. Qin, M. Manning, Z. Chen, M. Marquis, K.B. Averyt, M. Tignor and H.L. Miller (eds.)]. Cambridge University Press, Cambridge, United Kingdom and New York, NY, USA.

Jourau. T, T. Barnett, J. Adam, D. Lettenmaier. (2005) Potential impacts of a warming climate on water avalibility in snow-dominated regions. Nature. (438): $303-309$.

Kalra, A., T. C. Piechota, R. Davis, and G. A. Tootle. (2008). Changes in U.S. Streamflow and Western U.S. Snowpack. Journal of Hydrological Engineering. (13): $156-163$

Knowles, N., M. D. Dettinger, and D. R. Cayan. (2006). Trends in Snowfall versus Rainfall in the Western United States. Journal of Climate. (19): 4545 - 4559.

McCabe, G., J. (2003). Trends and variability in snowmelt runoff in the western United States. Journal of Hydrometeorology. (6): 476 - 482.

Milly, P. C. D., J. Betancourt, M. Falkenmark, R. M. Hirsch, Z. W. Kundzewicz, D. P. Lettenmaier and R. J. Stouffer. (2008). Stationarity Is Dead: Whither Water Management? Science. (319): 573 - 574.

Mote, P. W. (2003). Trends in the snow water equivalent in the Pacific Northwest and their climatic causes. Geophysics Research Letters (30): 1601, doi: 10.1029/2003GL017258, 12.

Mote, P. W., A. F. Hamlet, M. P. Clark, and D. P. Lettenmaier. (2005) Declining mountain snowpack in western North America. Bulletin of American Meteorological Society (86): 1-39.

Mote, P.W. (2006). Climate driven variability and trends in mountain snowpack in western North America. Journal of Climate. (19): 6209 - 6220. 
Nijssen, B., G. M. O’Donnell,A. F. Hamlet, and D. P. Lettenmaier. (2001). Hydrologic sensitivity of global rivers to climate change. Climatic Change. (50): 143-175.

Regonda, S., M. P. Clark, B. Rajagopalan, and J. Pitlick. (2005). Seasonal cycle shifts in hydroclimatology over the western United States. Journal of Climate. (18): 372384.

Serreze, M. C., M. P. Clark, R. L. Armstrong, D. A. McGinnis, and R. S. Pulwarty. (1999). Characteristics of the western United States snowpack from snowpack telemetry (SNOTEL) data. Water Resource Research. (35): 2145-2160.

Stewart, I. T. (2009). Changes in snowpack and snowmelt runoff for key mountain regions. Hydrological Processes. (23): 78 - 94.

Stewart, I. T., D. R. Cayan, and M. D. Dettinger. (2005). Changes toward earlier streamflow timing across Western North America. Journal of Climate. (18): 1136 -1155 . 


\section{APPENDIX}

Table A1 Linear Regression and Runs Test for all 20 SNOTEL Stations used for this study

\begin{tabular}{|c|c|c|c|c|c|c|c|c|c|}
\hline $\begin{array}{l}\text { Station } \\
\text { Name }\end{array}$ & & spps test & & Jan & Feb & Mar & Apr & May & June \\
\hline \multirow{15}{*}{$\begin{array}{l}\text { Freemont } \\
\text { Pass } \\
(485)\end{array}$} & \multirow[t]{5}{*}{ SWE } & Linear & $\operatorname{adj} \mathrm{r} 2$ & -0.034 & -0.03 & -0.019 & -0.031 & -0.018 & -0.021 \\
\hline & & Regression & sig & 0.843 & 0.698 & 0.502 & 0.721 & 0.492 & 0.535 \\
\hline & & & B & 0.166 & 0.251 & 0.396 & 0.197 & 0.293 & -0.142 \\
\hline & & runs test & Z-score & -0.162 & 0.039 & 0.29 & 0.29 & 0.29 & 0 \\
\hline & & & sig & 0.871 & 0.969 & 0.772 & 0.772 & 0.772 & 1 \\
\hline & \multirow[t]{5}{*}{ MAT } & Linear & adj r2 & 0.125 & 0.012 & 0.225 & 0.307 & 0.371 & 0.547 \\
\hline & & Regression & sig & 0.031 & 0.256 & 0.005 & 0.001 & 0 & 0 \\
\hline & & & $\mathrm{B}$ & 0.603 & 0.375 & 0.874 & 1.359 & 1.704 & 1.547 \\
\hline & & runs test & Z-score & -0.908 & -0.162 & -0.846 & -3.838 & -0.77 & -1.282 \\
\hline & & & sig & 0.364 & 0.871 & 0.398 & 0 & 0.441 & 0.2 \\
\hline & \multirow[t]{5}{*}{ MinAAT } & Linear & adj r2 & -0.036 & -0.036 & -0.025 & 0.059 & -0.036 & 0.65 \\
\hline & & Regression & $\operatorname{sig}$ & 0.956 & 0.956 & 0.586 & 0.105 & 0.94 & 0.093 \\
\hline & & & B & -0.009 & -0.008 & 0.093 & 0.191 & -0.018 & 0.168 \\
\hline & & runs test & z-score & -0.186 & -0.929 & -0.846 & -1.19 & 1.047 & 0.401 \\
\hline & & & sig & 0.853 & 0.353 & 0.398 & 0.234 & 0.295 & 0.688 \\
\hline \multirow{15}{*}{$\begin{array}{l}\text { Hoosier } \\
\text { Pass } \\
(531)\end{array}$} & \multirow[t]{5}{*}{ SWE } & Linear & adj r2 & -0.032 & -0.035 & -0.03 & -0.035 & -0.036 & 0.04 \\
\hline & & Regression & $\operatorname{sig}$ & 0.756 & 0.858 & 0.709 & 0.931 & 0.951 & 0.148 \\
\hline & & & B & -0.264 & 0.114 & 0.211 & 0.048 & -0.021 & 0.325 \\
\hline & & runs test & Z-score & -0.162 & -2.415 & -1.512 & -0.929 & -1.603 & -1.61 \\
\hline & & & sig & 0.871 & 0.016 & 0.131 & 0.353 & 0.109 & 0.107 \\
\hline & \multirow[t]{5}{*}{ MAT } & Linear & adj r2 & 0.03 & -0.035 & 0.121 & 0.037 & 0.156 & 0.242 \\
\hline & & Regression & sig & 0.18 & 0.903 & 0.034 & 0.158 & 0.017 & 0.004 \\
\hline & & & B & 0.495 & 0.051 & 0.87 & 0.731 & 1.479 & 0.693 \\
\hline & & runs test & Z-score & -1.512 & -1.603 & -0.908 & -0.186 & -0.162 & -0.323 \\
\hline & & & sig & 0.131 & 0.109 & 0.364 & 0.853 & 0.871 & 0.747 \\
\hline & \multirow[t]{5}{*}{ MinAAT } & Linear & $\operatorname{adj} \mathrm{r} 2$ & -0.029 & -0.036 & -0.03 & -0.034 & -0.021 & 0.159 \\
\hline & & Regression & sig & 0.684 & 0.941 & 0.709 & 0.851 & 0.537 & 0.018 \\
\hline & & & B & -0.066 & 0.009 & -0.075 & -0.043 & -0.163 & 0.233 \\
\hline & & runs test & z-score & -0.908 & 0 & 1.03 & 0.426 & 0.958 & -0.041 \\
\hline & & & sig & 0.346 & 1 & 0.303 & 0.67 & 0.338 & 0.967 \\
\hline
\end{tabular}


Table A1 Continued

Linear Regression and Runs Test for all 20 SNOTEL Stations used for this study

\begin{tabular}{|c|c|c|c|c|c|c|c|c|c|}
\hline $\begin{array}{l}\text { Station } \\
\text { Name } \\
\end{array}$ & variable & spps test & & Jan & Feb & Mar & Apr & May & June \\
\hline \multirow{15}{*}{$\begin{array}{l}\text { Berhoud } \\
\text { Summit } \\
(335)\end{array}$} & \multirow[t]{5}{*}{ SWE } & Linear & adj $\mathrm{r} 2$ & -0.035 & -0.033 & -0.028 & -0.031 & -0.03 & -0.013 \\
\hline & & \multirow[t]{2}{*}{ Regression } & sig & 0.911 & 0.789 & 0.694 & 0.736 & 0.701 & 0.434 \\
\hline & & & B & -0.096 & 0.175 & 0.259 & -0.144 & -0.1 & 0.157 \\
\hline & & \multirow[t]{2}{*}{ runs test } & z-score & -0.846 & -1.672 & -0.908 & 1.332 & 0 & 0.29 \\
\hline & & & sig & 0.398 & 0.094 & 0.364 & 0.183 & 1 & 0.772 \\
\hline & \multirow[t]{5}{*}{ MAT } & Linear & $\operatorname{adj} r 2$ & 0.214 & 0.151 & 0.39 & 0.252 & 0.245 & 0.322 \\
\hline & & \multirow[t]{2}{*}{ Regression } & sig & 0.006 & 0.019 & 0 & 0.003 & 0.003 & 0.001 \\
\hline & & & $\mathrm{B}$ & 0.824 & 0.973 & 1.366 & 1.38 & 1.648 & 1.014 \\
\hline & & \multirow[t]{2}{*}{ runs test } & z-score & -2.287 & -1.282 & -1.783 & -1.853 & -0.162 & -1.658 \\
\hline & & & sig & 0.022 & 0.2 & 0.075 & 0.064 & 0.871 & 0.097 \\
\hline & \multirow[t]{5}{*}{ MinAT } & Linear & $\operatorname{adj} r 2$ & 0.024 & 0.018 & 0.027 & 0.055 & -0.034 & 0.128 \\
\hline & & \multirow[t]{2}{*}{ Regression } & sig & 0.201 & 0.255 & 0.193 & 0.116 & 0.85 & 0.032 \\
\hline & & & B & 0.243 & 0.251 & 0.375 & 0.388 & 0.059 & 0.227 \\
\hline & & \multirow[t]{2}{*}{ runs test } & z-score & -1.655 & 0 & 1.589 & -0.323 & 1.301 & -2.681 \\
\hline & & & sig & 0.098 & 1 & 0.112 & 0.747 & 0.193 & 0.007 \\
\hline \multirow{15}{*}{$\begin{array}{l}\text { Grizzley } \\
\text { Peak } \\
(505)\end{array}$} & \multirow[t]{5}{*}{ SWE } & Linear & $\operatorname{adj} \mathrm{r} 2$ & -0.018 & -0.022 & -0.018 & -0.021 & -0.034 & -0.01 \\
\hline & & \multirow[t]{2}{*}{ Regression } & sig & 0.491 & 0.549 & 0.487 & 0.528 & 0.824 & 0.409 \\
\hline & & & B & 0.447 & 0.287 & 0.282 & 0.225 & 0.053 & 0.194 \\
\hline & & \multirow[t]{2}{*}{ runs test } & z-score & -0.846 & -0.908 & -0.929 & 0.039 & 0 & -0.174 \\
\hline & & & sig & 0.398 & 0.364 & 0.353 & 0.969 & 1 & 0.862 \\
\hline & \multirow[t]{5}{*}{ MAT } & Linear & $\operatorname{adj} \mathrm{r} 2$ & 0.366 & 0.129 & 0.363 & 0.14 & 0.132 & 0.33 \\
\hline & & \multirow[t]{2}{*}{ Regression } & sig & 0 & 0.027 & 0 & 0.241 & 0.02 & 0 \\
\hline & & & B & 1.667 & 1.312 & 1.803 & 0.618 & 1.572 & 1.287 \\
\hline & & \multirow[t]{2}{*}{ runs test } & z-score & -2.283 & -1.35 & -0.467 & -1.258 & 0.195 & -1.022 \\
\hline & & & sig & 0.022 & 0.177 & 0.641 & 0.208 & 0.845 & 0.307 \\
\hline & \multirow[t]{5}{*}{ MinAT } & Linear & $\operatorname{adj} \mathrm{r} 2$ & 0.118 & 0.024 & -0.026 & 0.114 & 0.003 & 0.225 \\
\hline & & \multirow[t]{2}{*}{ Regression } & sig & 0.035 & 0.204 & 0.58 & 0.044 & 0.308 & 0.005 \\
\hline & & & $\mathrm{B}$ & 0.251 & 0.191 & 0.165 & 0.393 & 0.127 & 0.998 \\
\hline & & \multirow[t]{2}{*}{ runs test } & z-score & 0.07 & 0 & 1.096 & -0.751 & 0.426 & 0.764 \\
\hline & & & sig & 0.944 & 1 & 0.273 & 0.453 & 0.67 & 0.445 \\
\hline
\end{tabular}


Table A1 Continued

Linear Regression and Runs Test for all 20 SNOTEL Stations used for this study

\begin{tabular}{|c|c|c|c|c|c|c|c|c|c|}
\hline $\begin{array}{l}\text { Station } \\
\text { Name }\end{array}$ & variable & spps test & & Jan & Feb & Mar & Apr & May & June \\
\hline \multirow{15}{*}{$\begin{array}{l}\text { Bison } \\
\text { Lake } \\
(345)\end{array}$} & \multirow[t]{5}{*}{ SWE } & Linear & adj r2 & -0.031 & -0.024 & -0.004 & 0.036 & 0.056 & 0.025 \\
\hline & & Regression & sig & 0.723 & 0.569 & 0.352 & 0.16 & 0.11 & 0.198 \\
\hline & & & $\mathrm{B}$ & -0.136 & -0.191 & -0.267 & -0.363 & -0.339 & -0.195 \\
\hline & & runs test & $\begin{array}{l}\mathrm{Z}- \\
\text { score }\end{array}$ & 0 & -0.349 & -0.349 & 0.039 & 0 & 0 \\
\hline & & & sig & 1 & 0.727 & 0.727 & 0.969 & 1 & 1 \\
\hline & \multirow[t]{5}{*}{ MAT } & Linear & adj r2 & 0.205 & -0.014 & 0.142 & -0.016 & -0.004 & 0.049 \\
\hline & & Regression & sig & 0.007 & 0.446 & 0.023 & 0.468 & 0.352 & 0.131 \\
\hline & & & B & 1.331 & 0.452 & 1.125 & 0.413 & 0.67 & 0.798 \\
\hline & & runs test & $\begin{array}{l}\mathrm{Z}- \\
\text { score }\end{array}$ & -0.935 & -1.603 & 0.186 & -0.557 & -0.162 & 0 \\
\hline & & & sig & 0.35 & 0.109 & 0.853 & 0.577 & 0.871 & 1 \\
\hline & \multirow[t]{5}{*}{ MinAT } & Linear & $\operatorname{adj} \mathrm{r} 2$ & 0.005 & 0.028 & 0.069 & 0.002 & -0.036 & 0.11 \\
\hline & & Regression & sig & 0.291 & 0.187 & 0.086 & 0.315 & 0.96 & 0.044 \\
\hline & & & B & 0.297 & 0.343 & 0.531 & 0.36 & -0.015 & 0.715 \\
\hline & & runs test & $\begin{array}{l}\text { Z- } \\
\text { score }\end{array}$ & -1.603 & -0.557 & -0.929 & 0.039 & 1.672 & 0 \\
\hline & & & sig & 0.109 & 0.557 & 0.353 & 0.969 & 0.094 & 1 \\
\hline \multirow{15}{*}{$\begin{array}{l}\text { Schofield } \\
\text { Pass } \\
(737)\end{array}$} & \multirow[t]{5}{*}{ SWE } & Linear & adj r2 & -0.036 & -0.029 & -0.034 & -0.012 & -0.005 & -0.027 \\
\hline & & Regression & sig & 0.955 & 0.662 & 0.818 & 0.423 & 0.364 & 0.63 \\
\hline & & & B & -0.022 & 0.132 & -0.052 & -0.165 & -0.131 & -0.051 \\
\hline & & runs test & $\begin{array}{l}\mathrm{Z}- \\
\text { score }\end{array}$ & -0.349 & -1.301 & -0.349 & -0.535 & 0.227 & 0.49 \\
\hline & & & sig & 0.727 & 0.193 & 0.727 & 0.593 & 0.82 & 0.624 \\
\hline & \multirow[t]{5}{*}{ MAT } & Linear & $\operatorname{adj} \mathrm{r} 2$ & 0.229 & 0.065 & 0.17 & 0.2 & 0.04 & 0.154 \\
\hline & & Regression & sig & 0.004 & 0.097 & 0.015 & 0.218 & 0.153 & 0.022 \\
\hline & & & B & 1.424 & 1.102 & 1.356 & 0.767 & 1.181 & 1.425 \\
\hline & & runs test & $\begin{array}{l}\mathrm{Z}- \\
\text { score }\end{array}$ & -0.162 & -1.508 & 0 & -1.224 & 0.442 & -0.871 \\
\hline & & & sig & 0.871 & 0.132 & 1 & 0.221 & 0.659 & 0.384 \\
\hline & \multirow[t]{5}{*}{ MinAT } & Linear & adj r2 & -0.015 & -0.022 & -0.02 & 0.006 & -0.032 & 0.091 \\
\hline & & Regression & sig & 0.459 & 0.53 & 0.504 & 0.29 & 0.722 & 0.062 \\
\hline & & & B & 0.219 & 0.191 & 0.25 & 0.328 & 0.109 & 0.662 \\
\hline & & runs test & $\begin{array}{l}\mathrm{Z}- \\
\text { score }\end{array}$ & 0.212 & 1.589 & 0.949 & -0.557 & 1.589 & 0.168 \\
\hline & & & sig & 0.832 & 0.112 & 0.343 & 0.577 & 0.112 & 0.866 \\
\hline
\end{tabular}


Table A1 Continued

Linear Regression and Runs Test for all 20 SNOTEL Stations used for this study

\begin{tabular}{|c|c|c|c|c|c|c|c|c|c|}
\hline $\begin{array}{l}\text { Station } \\
\text { Name }\end{array}$ & variable & spps test & & Jan & Feb & Mar & Apr & May & June \\
\hline \multirow{15}{*}{$\begin{array}{l}\text { Lake } \\
\text { Irene } \\
(565)\end{array}$} & \multirow[t]{5}{*}{ SWE } & Linear & $\operatorname{adj} r 2$ & -0.029 & -0.02 & -0.018 & 0.012 & -0.018 & -0.032 \\
\hline & & \multirow[t]{2}{*}{ Regression } & sig & 0.662 & 0.52 & 0.495 & 0.253 & 0.493 & 0.745 \\
\hline & & & B & -0.244 & -0.291 & -0.237 & -0.33 & -0.14 & 0.052 \\
\hline & & \multirow[t]{2}{*}{ runs test } & z-score & 0.426 & 0 & 0 & 1.332 & 1.436 & 0.958 \\
\hline & & & sig & 0.67 & 1 & 1 & 0.183 & 0.154 & 0.338 \\
\hline & \multirow[t]{5}{*}{ MAT } & Linear & $\operatorname{adj} r 2$ & 0.021 & -0.033 & 0.062 & 0.031 & 0.153 & 0.276 \\
\hline & & \multirow[t]{2}{*}{ Regression } & sig & 0.209 & 0.801 & 0.099 & 0.172 & 0.017 & 0.002 \\
\hline & & & B & 0.466 & -0.166 & 0.748 & 0.764 & 1.794 & 1.276 \\
\hline & & \multirow[t]{2}{*}{ runs test } & z-score & -0.44 & -0.35 & -0.162 & -0.315 & 0.151 & -1.129 \\
\hline & & & $\operatorname{sig}$ & 0.66 & 0.726 & 0.871 & 0.752 & 0.88 & 0.259 \\
\hline & \multirow[t]{5}{*}{$\operatorname{MinAT}$} & Linear & $\operatorname{adj} r 2$ & 0.168 & 0.005 & 0.022 & 0.06 & -0.012 & 0.198 \\
\hline & & \multirow[t]{2}{*}{ Regression } & $\operatorname{sig}$ & 0.014 & 0.296 & 0.212 & 0.103 & 0.427 & 0.009 \\
\hline & & & B & 0.4 & 0.289 & 0.393 & 0.384 & -0.236 & 1.09 \\
\hline & & \multirow[t]{2}{*}{ runs test } & z-score & -1.301 & 0.587 & 1.729 & -0.186 & 0.628 & 0.764 \\
\hline & & & sig & 0.193 & 0.557 & 0.084 & 0.853 & 0.53 & 0.445 \\
\hline \multirow{15}{*}{$\begin{array}{l}\begin{array}{l}\text { Indepen } \\
\text { dence }\end{array} \\
\text { Pass } \\
(542)\end{array}$} & \multirow[t]{5}{*}{ SWE } & Linear & $\operatorname{adj} r 2$ & -0.033 & -0.02 & -0.028 & -0.036 & -0.033 & -0.036 \\
\hline & & Regression & sig & 0.793 & 0.517 & 0.653 & 0.976 & 0.773 & 0.973 \\
\hline & & & B & 0.225 & 0.453 & 0.272 & 0.016 & -0.082 & 0.012 \\
\hline & & runs test & z-score & -1.655 & -2.36 & -2.36 & 0.814 & -0.535 & 0.476 \\
\hline & & & sig & 0.098 & 0.018 & 0.018 & 0.416 & 0.593 & 0.634 \\
\hline & \multirow[t]{5}{*}{ MAT } & Linear & $\operatorname{adj} r 2$ & 0.364 & 0.128 & 0.349 & 0.28 & 0.301 & 0.381 \\
\hline & & \multirow[t]{2}{*}{ Regression } & sig & 0 & 0.03 & 0 & 0.002 & 0.001 & 0 \\
\hline & & & B & 1.606 & 1.254 & 1.684 & 1.968 & 1.632 & 1.913 \\
\hline & & \multirow[t]{2}{*}{ runs test } & z-score & 0.442 & -0.535 & 0 & -3.522 & -1.826 & -2.044 \\
\hline & & & sig & 0.659 & 0.593 & 1 & 0 & 0.068 & 0.041 \\
\hline & \multirow[t]{5}{*}{ MinAT } & Linear & $\operatorname{adj} r 2$ & -0.026 & 0.013 & 0.129 & 0.139 & 0.062 & 0.289 \\
\hline & & \multirow[t]{2}{*}{ Regression } & $\operatorname{sig}$ & 0.602 & 0.251 & 0.029 & 0.024 & 0.1 & 0.001 \\
\hline & & & B & 0.171 & 0.348 & 0.659 & 0.687 & 0.189 & 1.081 \\
\hline & & \multirow[t]{2}{*}{ runs test } & z-score & 0.442 & 0 & 0.585 & 0.585 & 1.301 & -0.467 \\
\hline & & & sig & 0.659 & 1 & 0.559 & 0.559 & 0.193 & 0.641 \\
\hline
\end{tabular}


Table A1 Continued

Linear Regression and Runs Test for all 20 SNOTEL Stations used for this study

\begin{tabular}{|c|c|c|c|c|c|c|c|c|c|}
\hline $\begin{array}{l}\text { Station } \\
\text { Name } \\
\end{array}$ & variable & spps test & & Jan & Feb & Mar & Apr & May & June \\
\hline \multirow{15}{*}{$\begin{array}{l}\text { Copper } \\
\text { Mountain } \\
(415)\end{array}$} & \multirow[t]{5}{*}{ SWE } & Linear & $\operatorname{adj} \mathrm{r} 2$ & -0.011 & 0.009 & 0.018 & -0.006 & -0.028 & 0.02 \\
\hline & & Regression & sig & 0.419 & 0.269 & 0.226 & 0.368 & 0.664 & 0.219 \\
\hline & & & B & 0.667 & 0.67 & 0.651 & 0.478 & 0.15 & 0.387 \\
\hline & & runs test & z-score & -0.088 & -0.976 & -0.162 & 0.039 & -1.603 & -0.49 \\
\hline & & & sig & 0.93 & 0.329 & 0.871 & 0.969 & 0.109 & 0.624 \\
\hline & \multirow[t]{5}{*}{ MAT } & Linear & $\operatorname{adj} r 2$ & 0.138 & 0.027 & 0.214 & 0.088 & 0.114 & 0.142 \\
\hline & & Regression & sig & 0.024 & 0.191 & 0.006 & 0.061 & 0.041 & 0.025 \\
\hline & & & B & 0.708 & 0.814 & 1.346 & 1.033 & 1.765 & 1.394 \\
\hline & & runs test & z-score & -0.929 & -0.846 & -0.162 & -0.467 & 0.743 & -2.266 \\
\hline & & & sig & 0.354 & 0.398 & 0.871 & 0.641 & 0.458 & 0.023 \\
\hline & \multirow[t]{5}{*}{ MinAT } & Linear & adj r2 & -0.007 & -0.008 & -0.014 & 0.183 & -0.037 & 0.312 \\
\hline & & Regression & sig & 0.383 & 0.388 & 0.45 & 0.011 & 0.93 & 0.001 \\
\hline & & & B & 0.268 & 0.238 & 0.25 & 0.725 & 0.027 & 1.462 \\
\hline & & runs test & z-score & -0.186 & -1.282 & 1.426 & -0.557 & 2.51 & -0.222 \\
\hline & & & sig & 0.853 & 0.2 & 0.154 & 0.557 & 0.012 & 0.824 \\
\hline \multirow{15}{*}{$\begin{array}{l}\text { Vail } \\
\text { Mountain } \\
(842)\end{array}$} & \multirow[t]{5}{*}{ SWE } & Linear & $\operatorname{adj} \mathrm{r} 2$ & -0.021 & -0.035 & -0.034 & 0.02 & 0.063 & -0.025 \\
\hline & & Regression & sig & 0.531 & 0.885 & 0.85 & 0.218 & 0.097 & 0.6 \\
\hline & & & B & -0.418 & -0.069 & -0.08 & -0.363 & -0.353 & -0.103 \\
\hline & & runs test & z-score & -0.088 & 0.07 & 0.227 & 0.585 & 1.426 & -0.935 \\
\hline & & & sig & 0.93 & 0.944 & 0.82 & 0.559 & 0.154 & 0.35 \\
\hline & \multirow[t]{5}{*}{ MAT } & Linear & adj r2 & 0.299 & 0.014 & 0.153 & 0.021 & 0.032 & 0.127 \\
\hline & & Regression & sig & 0.001 & 0.243 & 0.019 & 0.213 & 0.174 & 0.03 \\
\hline & & & B & 1.562 & 0.718 & 1.078 & 0.722 & 0.999 & 1.108 \\
\hline & & runs test & z-score & -0.908 & 0.212 & 0.212 & -1.224 & 0.29 & -1.282 \\
\hline & & & sig & 0.364 & 0.832 & 0.832 & 0.221 & 0.772 & 0.2 \\
\hline & \multirow[t]{5}{*}{ MinAT } & Linear & adj r2 & -0.004 & 0.002 & 0.026 & 0.048 & -0.035 & 0.019 \\
\hline & & Regression & sig & 0.352 & 0.314 & 0.195 & 0.127 & 0.881 & 0.221 \\
\hline & & & B & 0.298 & 0.218 & 0.382 & 0.655 & 0.05 & 0.371 \\
\hline & & runs test & z-score & -0.908 & 0 & -0.349 & 1.426 & 1.589 & -0.162 \\
\hline & & & sig & 0.364 & 1 & 0.727 & 0.154 & 0.112 & 0.871 \\
\hline
\end{tabular}


Table A1 Continued

Linear Regression and Runs Test for all 20 SNOTEL Stations used for this study

\begin{tabular}{|c|c|c|c|c|c|c|c|c|c|}
\hline $\begin{array}{l}\text { Station } \\
\text { Name }\end{array}$ & variable & spps test & & Jan & Feb & Mar & Apr & May & June \\
\hline \multirow{15}{*}{$\begin{array}{l}\text { Mesa } \\
\text { Lake } \\
(622)\end{array}$} & \multirow[t]{5}{*}{ SWE } & Linear & $\operatorname{adj} \mathrm{r} 2$ & -0.036 & -0.019 & 0.003 & 0.056 & 0 & -0.037 \\
\hline & & Regression & sig & 0.871 & 0.498 & 0.305 & 0.115 & 0.327 & 0.965 \\
\hline & & & B & -0.107 & -0.318 & -0.382 & -0.511 & -0.219 & -0.011 \\
\hline & & runs test & z-score & -0.222 & -1.887 & -0.868 & -1.088 & -1.393 & 0.984 \\
\hline & & & sig & 0.824 & 0.059 & 0.386 & 0.277 & 0.164 & 0.325 \\
\hline & \multirow[t]{5}{*}{ MAT } & Linear & $\operatorname{adj} r 2$ & 0.468 & 0.029 & 0.185 & -0.001 & 0.019 & 0.14 \\
\hline & & Regression & sig & 0 & 0.188 & 0.011 & 0.334 & 0.224 & 0.028 \\
\hline & & & $\mathrm{B}$ & 1.982 & 0.675 & 1.045 & 0.549 & 0.847 & 1.14 \\
\hline & & runs test & z-score & -1.44 & -1.008 & 0.007 & -0.062 & -0.612 & -0.578 \\
\hline & & & sig & 0.15 & 0.277 & 0.995 & 0.95 & 0.54 & 0.563 \\
\hline & \multirow[t]{5}{*}{$\operatorname{MinAT}$} & Linear & $\operatorname{adj}$ r2 & 0.026 & 0.094 & 0.078 & -0.007 & 0.062 & 0.073 \\
\hline & & Regression & sig & 0.193 & 0.055 & 0.074 & 0.381 & 0.099 & 0.081 \\
\hline & & & B & 0.349 & 0.342 & 0.494 & 0.358 & 0.132 & 0.231 \\
\hline & & runs test & z-score & 0 & 0.309 & -1.129 & 1.521 & 0.385 & -1.129 \\
\hline & & & sig & 1 & 0.757 & 0.259 & 0.128 & 0.7 & 0.259 \\
\hline \multirow{15}{*}{$\begin{array}{l}\text { Klin } \\
(556)\end{array}$} & \multirow[t]{5}{*}{ SWE } & Linear & $\operatorname{adj} r 2$ & -0.022 & -0.033 & -0.035 & -0.032 & -0.019 & -0.028 \\
\hline & & Regression & sig & 0.536 & 0.78 & 0.872 & 0.762 & 0.51 & 0.644 \\
\hline & & & $\mathrm{B}$ & -0.067 & 0.223 & 0.105 & -0.158 & -0.206 & -0.556 \\
\hline & & runs test & z-score & -0.174 & 0.227 & -0.467 & -0.349 & -0.467 & 0 \\
\hline & & & sig & 0.862 & 0.82 & 0.641 & 0.727 & 0.641 & 1 \\
\hline & \multirow[t]{5}{*}{ MAT } & Linear & $\operatorname{adj} r 2$ & 0.268 & 0.071 & 0.082 & -0.013 & -0.011 & 0.089 \\
\hline & & Regression & sig & 0.002 & 0.88 & 0.073 & 0.431 & 0.41 & 0.063 \\
\hline & & & B & 1.654 & 0.972 & 1.002 & 0.545 & 0.594 & 1.203 \\
\hline & & runs test & z-score & -0.706 & -0.612 & 0 & 0 & 0.385 & -0.323 \\
\hline & & & sig & 0.48 & 0.54 & 1 & 1 & 0.7 & 0.747 \\
\hline & \multirow[t]{5}{*}{$\operatorname{Min} A T$} & Linear & $\operatorname{adj} r 2$ & -0.003 & -0.003 & 0.082 & -0.034 & -0.033 & 0.297 \\
\hline & & Regression & sig & 0.348 & 0.348 & 0.072 & 0.786 & 0.751 & 0.001 \\
\hline & & & $\mathrm{B}$ & 0.341 & 0.341 & 0.573 & 0.066 & 0.092 & 1.089 \\
\hline & & runs test & z-score & 0 & 0 & -0.372 & -0.323 & 0.949 & -1.887 \\
\hline & & & sig & 1 & 1 & 0.71 & 0.747 & 0.343 & 0.059 \\
\hline
\end{tabular}


Table A1 Continued

Linear Regression and Runs Test for all 20 SNOTEL Stations used for this study

\begin{tabular}{|c|c|c|c|c|c|c|c|c|c|}
\hline $\begin{array}{l}\text { Station } \\
\text { Name }\end{array}$ & variable & spps test & & Jan & Feb & Mar & Apr & May & June \\
\hline Willow & SWE & Linear & $\operatorname{adj} \mathrm{r} 2$ & -0.03 & -0.035 & -0.033 & -0.028 & -0.036 & -0.018 \\
\hline Creek & & Regression & $\operatorname{sig}$ & 0.709 & 0.911 & 0.776 & 0.652 & 0.944 & 0.491 \\
\hline Pass & & & B & -0.302 & -0.079 & -0.164 & -0.223 & -0.023 & 0.204 \\
\hline \multirow[t]{12}{*}{ (869) } & & runs test & z-score & 0.039 & 0 & 0.585 & 1.426 & 0.669 & 0.846 \\
\hline & & & sig & 0.969 & 1 & 0.559 & 0.154 & 0.504 & 0.397 \\
\hline & MAT & Linear & $\operatorname{adj} r 2$ & -0.02 & -0.035 & 0.068 & 0.02 & 0.045 & 0.214 \\
\hline & & Regression & sig & 0.505 & 0.937 & 0.089 & 0.218 & 0.134 & 0.007 \\
\hline & & & $\mathrm{B}$ & 0.254 & 0.032 & 0.801 & 0.736 & 1.03 & 1.049 \\
\hline & & runs test & z-score & -0.706 & -1.377 & -0.186 & -0.737 & 1.977 & -1.129 \\
\hline & & & sig & 0.48 & 0.168 & 0.853 & 0.461 & 0.048 & 0.259 \\
\hline & MinAT & Linear & $\operatorname{adj} r 2$ & 0.003 & 0.007 & -0.028 & -0.025 & -0.028 & 0.108 \\
\hline & & Regression & $\operatorname{sig}$ & 0.307 & 0.281 & 0.658 & 0.601 & 0.649 & 0.046 \\
\hline & & & $\mathrm{B}$ & -0.165 & -0.167 & -0.081 & 0.099 & -0.097 & 1.036 \\
\hline & & runs test & z-score & -2.775 & -0.35 & -0.535 & -0.737 & 0.186 & -1.27 \\
\hline & & & sig & 0.006 & 0.726 & 0.593 & 0.461 & 0.853 & 0.204 \\
\hline \multirow{15}{*}{$\begin{array}{l}\text { McClure } \\
(618)\end{array}$} & SWE & Linear & $\operatorname{adj} r 2$ & -0.028 & -0.028 & -0.027 & 0.003 & 0.024 & -0.001 \\
\hline & & Regression & sig & 0.784 & 0.801 & 0.747 & 0.3 & 0.187 & 0.336 \\
\hline & & & $\mathrm{B}$ & -0.193 & 0.138 & 0.135 & -0.324 & -0.283 & -0.608 \\
\hline & & runs test & z-score & -0.682 & 0.826 & -0.107 & -0.301 & -0.679 & 0 \\
\hline & & & sig & 0.495 & 0.409 & 0.914 & 0.763 & 0.497 & 1 \\
\hline & MAT & Linear & $\operatorname{adj} r 2$ & 0.377 & 0.194 & 0.327 & 0.131 & 0.155 & 0.268 \\
\hline & & Regression & sig & 0 & 0.009 & 0.001 & 0.028 & 0.018 & 0.002 \\
\hline & & & B & 1.406 & 1.369 & 1.469 & 1.059 & 1.226 & 1.416 \\
\hline & & runs test & z-score & -1.603 & -1.981 & -0.162 & 0 & -1.655 & -1.393 \\
\hline & & & sig & 0.109 & 0.048 & 0.871 & 1 & 0.098 & 0.164 \\
\hline & MinAT & Linear & $\operatorname{adj} r 2$ & 0.076 & 0.012 & 0.236 & 0 & 0.057 & 0.353 \\
\hline & & Regression & sig & 0.089 & 0.261 & 0.004 & 0.326 & 0.113 & 0 \\
\hline & & & $\mathrm{B}$ & 0.545 & 0.266 & 0.801 & 0.27 & 0.167 & 1.094 \\
\hline & & runs test & z-score & -0.846 & 0.814 & -0.535 & 2.787 & -2.043 & -1.826 \\
\hline & & & sig & 0.398 & 0.416 & 0.593 & 0.005 & 0.041 & 0.068 \\
\hline
\end{tabular}


Table A1 Continued

Linear Regression and Runs Test for all 20 SNOTEL Stations used for this study

\begin{tabular}{|c|c|c|c|c|c|c|c|c|c|}
\hline $\begin{array}{l}\text { Station } \\
\text { Name }\end{array}$ & variable & spps test & & Jan & Feb & Mar & Apr & May & June \\
\hline Summit & SWE & Linear & $\operatorname{adj~r2}$ & -0.023 & -0.017 & -0.032 & -0.021 & 0.024 & -0.021 \\
\hline Ranch & & Regression & sig & 0.556 & 0.474 & 0.756 & 0.535 & 0.203 & 0.535 \\
\hline \multirow[t]{13}{*}{ (802) } & & & B & 0.71 & 0.62 & 0.227 & -0.348 & -0.42 & -1.835 \\
\hline & & runs test & z-score & 0.29 & 0 & 1.03 & 2.044 & -0.557 & 0 \\
\hline & & & sig & 0.772 & 1 & 0.303 & 0.041 & 0.577 & 1 \\
\hline & MAT & Linear & $\operatorname{adj} \mathrm{r} 2$ & 0.074 & 0.044 & 0.259 & 0.089 & 0.211 & 0.301 \\
\hline & & Regre & sig & 0.079 & 0.138 & 0.002 & 0.06 & 0.006 & 0.001 \\
\hline & & & B & 0.647 & 0.213 & 0.949 & 1.063 & 1.528 & 1.594 \\
\hline & & runs test & z-score & -2.402 & -0.737 & -0.186 & -1.124 & 0.628 & -1.003 \\
\hline & & & sig & 0.016 & 0.461 & 0.853 & 0.261 & 0.53 & 0.316 \\
\hline & MinAT & Linear & $\operatorname{adj} \mathrm{r} 2$ & -0.035 & -0.034 & -0.032 & -0.032 & 0.01 & 0.232 \\
\hline & & Regression & sig & 0.903 & 0.856 & 0.739 & 0.767 & 0.264 & 0.005 \\
\hline & & & B & 0.016 & 0.023 & 0.042 & -0.063 & 0.124 & 1.016 \\
\hline & & runs test & z-score & -0.088 & -0.908 & 1.426 & -0.088 & 0.186 & -1.508 \\
\hline & & & sig & 0.93 & 0.364 & 0.154 & 0.93 & 0.853 & 0.132 \\
\hline \multirow{15}{*}{$\begin{array}{l}\text { North } \\
\text { Lost } \\
\text { Trail } \\
(669)\end{array}$} & SWE & Linear & $\operatorname{adj~r2}$ & -0.01 & -0.002 & -0.034 & -0.033 & -0.025 & -0.035 \\
\hline & & Regression & sig & 0.402 & 0.338 & 0.825 & 0.782 & 0.6 & 0.936 \\
\hline & & & B & 0.561 & 0.445 & 0.082 & -0.084 & -0.118 & 0.04 \\
\hline & & runs test & z-score & -1.224 & -0.467 & 0.814 & 0.585 & -0.467 & 0 \\
\hline & & & sig & 0.221 & 0.641 & 0.416 & 0.559 & 0.641 & 1 \\
\hline & MAT & Lin & adj r2 & 3 & 0.049 & 0.179 & 0.039 & 0.02 & 0.121 \\
\hline & & Regression & sig & & 0.129 & 0.011 & 0.151 & 0.225 & 0.039 \\
\hline & & & B & & 0.912 & 1.105 & 0.918 & 0.911 & 1.154 \\
\hline & & runs test & z-score & 0 & -0.751 & 0.929 & 0 & 0.608 & -0.166 \\
\hline & & & sig & 1 & 0.453 & 0.353 & 1 & 0.543 & 0.868 \\
\hline & MinAT & Linear & $\operatorname{adj~} \mathrm{r} 2$ & 0.2 & 0.114 & 0.07 & 0 & -0.026 & 0.066 \\
\hline & & Regression & sig & 0.009 & 0.038 & 0.085 & 0.324 & 0.583 & 0.101 \\
\hline & & & B & 0.234 & 0.272 & 0.224 & 0.334 & 0.184 & 0.635 \\
\hline & & runs test & z-score & 0.483 & 0.039 & 0 & 2.183 & 1.096 & -0.166 \\
\hline & & & sig & 0.629 & 0.969 & 1 & 0.029 & 0.273 & 0.868 \\
\hline
\end{tabular}


Table A1 Continued

Linear Regression and Runs Test for all 20 SNOTEL Stations used for this study

\begin{tabular}{|c|c|c|c|c|c|c|c|c|c|}
\hline $\begin{array}{l}\text { Station } \\
\text { Name } \\
\end{array}$ & variable & spps test & & Jan & Feb & Mar & Apr & May & June \\
\hline \multirow{15}{*}{$\begin{array}{l}\text { Phantom } \\
\text { Valley } \\
(688)\end{array}$} & \multirow[t]{5}{*}{ SWE } & Linear & $\operatorname{adj} \mathrm{r} 2$ & -0.033 & -0.036 & -0.036 & -0.022 & -0.031 & 0.001 \\
\hline & & \multirow[t]{2}{*}{ Regression } & sig & 0.806 & 0.962 & 0.945 & 0.547 & 0.736 & 0.332 \\
\hline & & & B & -0.337 & 0.049 & 0.057 & -0.282 & 0.118 & 0.934 \\
\hline & & \multirow[t]{2}{*}{ runs test } & z-score & 0.557 & 1.426 & 0.814 & 1.301 & 0.227 & 0 \\
\hline & & & sig & 0.577 & 0.154 & 0.416 & 0.193 & 0.82 & 1 \\
\hline & \multirow[t]{5}{*}{ MAT } & Linear & $\operatorname{adj} r 2$ & 0.216 & 0.028 & 0.087 & 0.025 & 0.08 & 0.189 \\
\hline & & \multirow[t]{2}{*}{ Regression } & sig & 0.006 & 0.185 & 0.06 & 0.193 & 0.067 & 0.008 \\
\hline & & & B & 1.341 & 0.77 & 1.026 & 0.873 & 1.102 & 0.904 \\
\hline & & \multirow[t]{2}{*}{ runs test } & z-score & -0.908 & -0.737 & -1.791 & -0.6 & 1.848 & -0.467 \\
\hline & & & sig & 0.364 & 0.461 & 0.073 & 0.549 & 0.065 & 0.641 \\
\hline & \multirow[t]{5}{*}{ MinAT } & Linear & $\operatorname{adj} r 2$ & 0.118 & 0.047 & -0.033 & -0.002 & -0.028 & 0.108 \\
\hline & & \multirow[t]{2}{*}{ Regression } & sig & 0.036 & 0.13 & 0.772 & 0.337 & 0.651 & 0.042 \\
\hline & & & B & 0.699 & 0.342 & 0.085 & 0.213 & -0.124 & 1.224 \\
\hline & & \multirow[t]{2}{*}{ runs test } & z-score & -2.028 & -1.224 & 1.301 & -0.186 & 0.29 & 0 \\
\hline & & & sig & 0.043 & 0.221 & 0.193 & 0.853 & 0.772 & 1 \\
\hline \multirow{15}{*}{$\begin{array}{l}\text { Lynx } \\
\text { Pass } \\
(607)\end{array}$} & \multirow[t]{5}{*}{$\overline{S W E}$} & Linear & $\operatorname{adj} r 2$ & -0.036 & -0.025 & -0.035 & -0.01 & -0.033 & -0.021 \\
\hline & & \multirow[t]{2}{*}{ Regression } & sig & 0.981 & 0.596 & 0.934 & 0.41 & 0.778 & 0.535 \\
\hline & & & B & -0.03 & 0.505 & 0.07 & -0.48 & -0.098 & -6.322 \\
\hline & & \multirow[t]{2}{*}{ runs test } & z-score & -0.575 & -0.467 & -0.349 & 0.669 & 0 & 0 \\
\hline & & & sig & 0.565 & 0.641 & 0.727 & 0.504 & 1 & 1 \\
\hline & \multirow[t]{5}{*}{ MAT } & Linear & $\operatorname{adj} r 2$ & -0.006 & -0.032 & 0.084 & 0.035 & 0.171 & 0.215 \\
\hline & & \multirow[t]{2}{*}{ Regression } & sig & 0.373 & 0.751 & 0.066 & 0.162 & 0.013 & 0.006 \\
\hline & & & B & 0.354 & 0.133 & 0.955 & 0.881 & 1.386 & 0.931 \\
\hline & & \multirow[t]{2}{*}{ runs test } & z-score & -0.846 & -0.737 & -0.186 & 0 & 0.186 & -0.535 \\
\hline & & & sig & 0.398 & 0.461 & 0.853 & 1 & 0.853 & 0.593 \\
\hline & \multirow[t]{5}{*}{ MinAT } & Linear & $\operatorname{adj} r 2$ & 0.028 & 0.012 & -0.014 & -0.026 & -0.005 & 0.095 \\
\hline & & \multirow[t]{2}{*}{ Regression } & sig & 0.186 & 0.254 & 0.442 & 0.614 & 0.363 & 0.054 \\
\hline & & & B & -0.206 & -0.181 & -0.143 & -0.101 & -0.247 & 0.953 \\
\hline & & \multirow[t]{2}{*}{ runs test } & z-score & -1.603 & 0.29 & 0.557 & -0.162 & 0.958 & -0.908 \\
\hline & & & sig & 0.109 & 0.772 & 0.577 & 0.871 & 0.338 & 0.364 \\
\hline
\end{tabular}


Table A1 Continued

Linear Regression and Runs Test for all 20 SNOTEL Stations used for this study

\begin{tabular}{|c|c|c|c|c|c|c|c|c|c|}
\hline $\begin{array}{l}\text { Station } \\
\text { Name } \\
\end{array}$ & variable & spps test & & Jan & Feb & Mar & Apr & May & June \\
\hline Still & SWE & Linear & $\operatorname{adj} r 2$ & 0.063 & 0.011 & -0.02 & -0.016 & -0.022 & * \\
\hline Water & & Regression & sig & 0.097 & 0.257 & 0.513 & 0.47 & 0.547 & \\
\hline Creek & & & B & 1.824 & 1.017 & 0.495 & -0.393 & -0.518 & \\
\hline \multirow[t]{12}{*}{ (793) } & & runs test & z-score & -0.186 & 0 & 0.039 & 2.078 & -0.112 & \\
\hline & & & sig & 0.853 & 1 & 0.969 & 0.038 & 0.911 & \\
\hline & MAT & Linear & $\operatorname{adj} \mathrm{r} 2$ & 0.31 & 0.027 & 0.241 & 0.081 & -0.005 & 0.099 \\
\hline & & Regre & sig & 0.001 & 0.189 & 0.004 & 0.07 & 0.362 & 0.05 \\
\hline & & & B & 1.632 & 0.768 & 1.276 & 1.076 & 0.696 & 1.067 \\
\hline & & runs test & z-score & -0.751 & -0.908 & 0 & 0.814 & 1.431 & -1.301 \\
\hline & & & sig & 0.453 & 0.364 & 1 & 0.416 & 0.152 & 0.193 \\
\hline & MinAT & Linear & $\operatorname{adj~} \mathrm{r} 2$ & 0.117 & -0.013 & 0.039 & 0.041 & -0.035 & 0.155 \\
\hline & & Regression & sig & 0.039 & 0.436 & 0.156 & 0.144 & 0.903 & 0.018 \\
\hline & & & B & 0.335 & 0.182 & 0.193 & 0.176 & 0.039 & 1.337 \\
\hline & & runs test & z-score & -1.129 & 0.227 & 0.483 & -0.045 & -0.186 & 0.227 \\
\hline & & & sig & 0.259 & 0.82 & 0.629 & 0.964 & 0.853 & 0.82 \\
\hline \multirow{15}{*}{$\begin{array}{l}\text { Nast } \\
\text { Lake } \\
\text { (658) }\end{array}$} & SWE & Linear & $\operatorname{adj} \mathrm{r} 2$ & -0.035 & -0.028 & -0.036 & 0.053 & -0.008 & -0.021 \\
\hline & & Regression & sig & 0.932 & 0.652 & 0.949 & 0.117 & 0.386 & 0.535 \\
\hline & & & B & -0.096 & 0.381 & 0.046 & -0.737 & -0.554 & -4.377 \\
\hline & & runs test & z-score & 0.958 & 0.91 & 0.227 & 0 & -1.552 & 0 \\
\hline & & & sig & 0.38 & 0.363 & 0.82 & 1 & 0.121 & 1 \\
\hline & MAT & Lin & adj r2 & 0.147 & $\begin{array}{l}-0.003 \\
\end{array}$ & 0.036 & -0.003 & -0.02 & 0.025 \\
\hline & & & sig & & 0. & 0.159 & 0.348 & 0.507 & 0.198 \\
\hline & & & B & 0.914 & 0.519 & 0.431 & 0.719 & -0.045 & 0.757 \\
\hline & & runs test & z-score & -0.908 & -1.393 & -0.088 & -0.612 & 0 & -0.737 \\
\hline & & & sig & 0.364 & 0.164 & 0.93 & 0.54 & 1 & 0.461 \\
\hline & MinAT & Linear & $\operatorname{adj~} \mathrm{r} 2$ & -0.014 & 0.031 & 0.194 & 0.366 & 0.307 & 0.158 \\
\hline & & Regression & sig & 0.445 & 0.175 & 0.009 & 0 & 0.001 & 0.017 \\
\hline & & & B & 0.244 & 0.383 & 0.645 & 0.474 & 0.381 & 0.196 \\
\hline & & runs test & z-score & -0.162 & -0.535 & -0.088 & -1.124 & -0.997 & -0.364 \\
\hline & & & sig & 0.871 & 0.593 & 0.93 & 0.261 & 0.319 & 0.716 \\
\hline
\end{tabular}

\footnotetext{
*no data
} 


\section{Table A2}

Change in temperature over time for all 20 SNOTEL stations

\begin{tabular}{|c|c|c|c|c|c|c|c|c|}
\hline $\begin{array}{l}\text { Station } \\
\text { Name }\end{array}$ & ID & variable & Jan & Feb & Mar & Apr & May & June \\
\hline \multirow{3}{*}{$\begin{array}{l}\text { Freemont } \\
\text { Pass }\end{array}$} & \multirow{2}{*}{485} & MAT & 0.603 & 0.375 & 0.874 & 1.359 & 1.704 & 1.547 \\
\hline & & MinAT & -0.009 & -0.008 & 0.093 & 0.191 & -0.018 & 0.168 \\
\hline & \multirow{2}{*}{531} & MAT & 0.495 & 0.051 & 0.87 & 0.731 & 1.479 & 0.693 \\
\hline Hoosier Pass & & $\operatorname{Min} A T$ & -0.066 & 0.009 & -0.075 & -0.043 & -0.163 & 0.233 \\
\hline Berhoud & \multirow{2}{*}{335} & MAT & 0.824 & 0.973 & 1.366 & 1.38 & 1.648 & 1.014 \\
\hline Summit & & $\operatorname{Min} A T$ & 0.243 & 0.251 & 0.375 & 0.388 & 0.059 & 0.227 \\
\hline \multirow{3}{*}{$\begin{array}{l}\text { Grizzley } \\
\text { Peak }\end{array}$} & \multirow{2}{*}{505} & MAT & 1.667 & 1.312 & 1.803 & 0.618 & 1.572 & 1.287 \\
\hline & & MinAT & 0.251 & 0.191 & 0.165 & 0.393 & 0.127 & 0.998 \\
\hline & \multirow{2}{*}{345} & MAT & 1.331 & 0.452 & 1.125 & 0.413 & 0.67 & 0.798 \\
\hline Bison Lake & & $\operatorname{Min} A T$ & 0.297 & 0.343 & 0.531 & 0.36 & -0.015 & 0.715 \\
\hline \multirow{2}{*}{$\begin{array}{l}\text { Schofield } \\
\text { Pass }\end{array}$} & \multirow{2}{*}{737} & MAT & 1.424 & 1.102 & 1.356 & 0.767 & 1.181 & 1.425 \\
\hline & & $\operatorname{Min} A T$ & 0.219 & 0.191 & 0.25 & 0.328 & 0.109 & 0.662 \\
\hline \multirow[b]{2}{*}{ Lake Irene } & \multirow{2}{*}{565} & MAT & 0.466 & -0.166 & 0.748 & 0.764 & 1.794 & 1.276 \\
\hline & & $\operatorname{Min} A T$ & 0.4 & 0.289 & 0.393 & 0.384 & -0.236 & 1.09 \\
\hline \multirow{2}{*}{$\begin{array}{l}\text { Independence } \\
\text { Pass }\end{array}$} & \multirow{2}{*}{542} & MAT & 1.606 & 1.254 & 1.684 & 1.968 & 1.632 & 1.913 \\
\hline & & MinAT & 0.171 & 0.348 & 0.659 & 0.687 & 0.189 & 1.081 \\
\hline \multirow{2}{*}{$\begin{array}{l}\text { Copper } \\
\text { Mountain }\end{array}$} & \multirow{2}{*}{415} & MAT & 0.708 & 0.814 & 1.346 & 1.033 & 1.765 & 1.394 \\
\hline & & $\operatorname{Min} A T$ & 0.268 & 0.238 & 0.25 & 0.725 & 0.027 & 1.462 \\
\hline \multirow{2}{*}{$\begin{array}{l}\text { Vail } \\
\text { Mountain }\end{array}$} & \multirow{2}{*}{842} & MAT & 1.562 & 0.718 & 1.078 & 0.722 & 0.999 & 1.108 \\
\hline & & $\operatorname{Min} A T$ & 0.298 & 0.218 & 0.382 & 0.655 & 0.05 & 0.371 \\
\hline \multirow{3}{*}{ Mesa Lake } & \multirow{2}{*}{622} & MAT & 1.982 & 0.675 & 1.045 & 0.549 & 0.847 & 1.14 \\
\hline & & $\operatorname{Min} A T$ & 0.349 & 0.342 & 0.494 & 0.358 & 0.132 & 0.231 \\
\hline & \multirow{2}{*}{556} & MAT & 1.654 & 0.972 & 1.002 & 0.545 & 0.594 & 1.203 \\
\hline Kiln & & $\operatorname{Min} A T$ & 0.341 & 0.341 & 0.573 & 0.066 & 0.092 & 1.089 \\
\hline \multirow{4}{*}{$\begin{array}{l}\text { Willow } \\
\text { Creek Pass } \\
\text { McClure }\end{array}$} & \multirow{2}{*}{869} & MAT & 0.254 & 0.032 & 0.801 & 0.736 & 1.03 & 1.049 \\
\hline & & MinAT & -0.165 & -0.167 & -0.081 & 0.099 & -0.097 & 1.036 \\
\hline & \multirow[t]{2}{*}{618} & MAT & 1.406 & 1.369 & 1.469 & 1.059 & 1.226 & 1.416 \\
\hline & & MinAT & 0.545 & 0.266 & 0.801 & 0.27 & 0.167 & 1.094 \\
\hline \multirow[t]{2}{*}{$\begin{array}{l}\text { Summit } \\
\text { Ranch }\end{array}$} & \multirow[t]{2}{*}{802} & MAT & 0.647 & 0.213 & 0.949 & 1.063 & 1.528 & 1.594 \\
\hline & & MinAT & 0.016 & 0.023 & 0.042 & -0.063 & 0.124 & 1.016 \\
\hline \multirow[t]{2}{*}{$\begin{array}{l}\text { North Lost } \\
\text { Trail }\end{array}$} & \multirow[t]{2}{*}{669} & MAT & & 0.912 & & & 0.9 & \\
\hline & & MinAT & 0.234 & 0.272 & 0.224 & 0.334 & 0.184 & 0.635 \\
\hline
\end{tabular}




\section{Table A2 Continued}

Change in temperature over time for all 20 SNOTEL stations

\begin{tabular}{|c|c|c|c|c|c|c|c|c|}
\hline $\begin{array}{l}\text { Station } \\
\text { Name }\end{array}$ & ID & variable & Jan & Feb & Mar & Apr & May & June \\
\hline Phantom & \multirow{2}{*}{688} & MAT & 1.341 & 0.77 & 1.026 & 0.873 & 1.102 & 0.904 \\
\hline Valley & & $\operatorname{Min} A T$ & 0.699 & 0.342 & 0.085 & 0.213 & -0.124 & 1.224 \\
\hline Lynx & \multirow{3}{*}{607} & MAT & 0.354 & 0.133 & 0.955 & 0.881 & 1.386 & 0.931 \\
\hline Pass & & MinAT & -0.206 & -0.181 & -0.143 & -0.101 & -0.247 & 0.953 \\
\hline Still & & MAT & 1.632 & 0.768 & 1.276 & 1.076 & 0.696 & 1.067 \\
\hline $\begin{array}{l}\text { Water } \\
\text { Creek }\end{array}$ & 793 & $\operatorname{Min} A T$ & 0.335 & 0.182 & 0.193 & 0.176 & 0.039 & 1.337 \\
\hline & \multirow{2}{*}{658} & MAT & 0.914 & 0.519 & 0.431 & 0.719 & -0.045 & 0.757 \\
\hline Nast Lake & & MinAT & 0.244 & 0.383 & 0.645 & 0.474 & 0.381 & 0.196 \\
\hline
\end{tabular}




\section{CURRICULUM VITA}

NAME:

ADDRESS:

DOB:

EDUCATION:
Claire-Louise Bode

12 Hendrik Street

Verwoerdpark

Alberton

1453

South Africa

Alberton, South Africa - May 21, 1991

B.S., Geography - Climatology

The Ohio State University

Columbus, $\mathrm{OH}$

$2010-2014$

M.S., Applied Geography

University of Louisville

Louisville, KY

2014 - 2016 